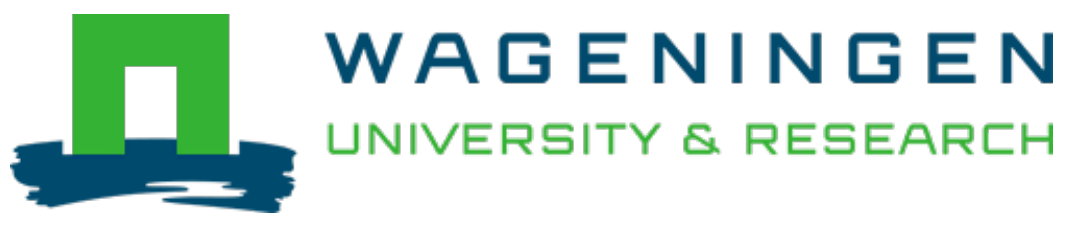

\title{
The uptake of biological control in Latin America and the Caribbean.
}

Biological control in Latin America and the Caribbean: its rich history and bright future

Lenteren, J.C.; Cock, M.J.W.

https://doi.org/10.1079/9781789242430.0473

This article is made publicly available in the institutional repository of Wageningen University and Research, under the terms of article $25 \mathrm{fa}$ of the Dutch Copyright Act, also known as the Amendment Taverne. This has been done with explicit consent by the author.

Article $25 \mathrm{fa}$ states that the author of a short scientific work funded either wholly or partially by Dutch public funds is entitled to make that work publicly available for no consideration following a reasonable period of time after the work was first published, provided that clear reference is made to the source of the first publication of the work.

This publication is distributed under The Association of Universities in the Netherlands (VSNU) 'Article 25fa implementation' project. In this project research outputs of researchers employed by Dutch Universities that comply with the legal requirements of Article $25 \mathrm{fa}$ of the Dutch Copyright Act are distributed online and free of cost or other barriers in institutional repositories. Research outputs are distributed six months after their first online publication in the original published version and with proper attribution to the source of the original publication.

You are permitted to download and use the publication for personal purposes. All rights remain with the author(s) and / or copyright owner(s) of this work. Any use of the publication or parts of it other than authorised under article $25 \mathrm{fa}$ of the Dutch Copyright act is prohibited. Wageningen University \& Research and the author(s) of this publication shall not be held responsible or liable for any damages resulting from your (re)use of this publication.

For questions regarding the public availability of this article please contact openscience.library@,wur.nl 


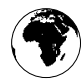 The Uptake of Biological Control
in Latin America and the
Caribbean
}

\author{
Joop C. van Lenteren ${ }^{1 \star}$ and Matthew J.W. Cock ${ }^{2}$ \\ ${ }^{1}$ Laboratory of Entomology, Wageningen University, \\ The Netherlands; ${ }^{2} \mathrm{CABI}$, Egham, UK
}

\begin{abstract}
Biological control started to be used in the 1880s in Latin America and the Caribbean and has since developed into a widely applied pest management method. Currently almost 32 million hectares are under classical, more than 31 million hectares under augmentative and hundreds of thousands of hectares under conservation biocontrol. Achievements in this region have been impressive and are documented in this chapter. Several factors frustrate the implementation of biocontrol on an even larger area. The most important are the dominance of the pesticide industry, the negative effect of pesticides on biological and natural pest control, governmental 'subsidies' to keep chemical control cheap, the lack of funding for research and implementation of biocontrol, and an expensive, time-consuming regulatory framework. However, inherent positive characteristics of biocontrol contribute to sustainable pest management, a healthier and biodiverse environment, pesticide-free food and improved yields. These characteristics, together with the large-scale natural enemy prospecting programmes, the documentation of the many cases of natural control and the successful regional collaboration on area-wide control of new invasive pests, point at a bright future for biocontrol in Latin America and the Caribbean.
\end{abstract}

\subsection{Introduction}

Since its first use in 1884 , biological control with arthropod natural enemies and microbial control agents has seen a strong increase in the number of species of biocontrol agents used and areas treated in Latin America and the Caribbean. Until 1970, mainly classical biocontrol was used, though in some countries augmentative biocontrol was employed as well; later, conservation biocontrol was applied and natural control was documented. Most first uses of biocontrol involved the release of invertebrate natural enemies, usually insect predators or parasitoids, but microbial agents and vertebrates were also used. Another characteristic of this early period in the Latin American region is that biocontrol was mainly aimed at insect control, with control of weeds and diseases of plants developing later.

Van Lenteren and Bueno (2003) concluded from data in the few published reviews concerning biocontrol in South and Central America and the Caribbean that in the period from 1880 to 1970,16 countries used classical biocontrol. Well known examples of early classical biocontrol for South America are the introduction of Rodolia cardinalis (Mulsant) for control of cottony cushion scale Icerya purchasi Maskell, the release of a species of Encarsia for control of the

\footnotetext{
* E-mail: joop.vanlenteren@wur.nl
} 
white peach scale Pseudaulacaspis pentagona (Targ-Tozz) and the introduction of Aphelinus mali (Hald.) for control of woolly apple aphid Eriosoma lanigerum (Hausmann), which have usually led to substantial or complete control in a number of countries. Examples of successful classical biocontrol for Central America and the Caribbean during this period are the complete biocontrol of the citrus blackfly Aleurocanthus woglumi Ashby as a result of inoculative releases with the parasitoid Eretmocerus serius Silv. and/ or Amitus hesperidium Silv. in Cuba, Costa Rica, Mexico and Panama; and the use of tachinid and hymenopteran parasitoids to control sugarcane borers on different Caribbean islands. Only four countries applied augmentative biocontrol before the 1970s and areas under biocontrol were seldom provided. Augmentative biocontrol concerned inundative releases with egg parasitoids of the genera Trichogramma and Telenomus to control pests in sugarcane.

Based on data in papers published since 1970 , and after obtaining information by contacting researchers in the region, van Lenteren and Bueno (2003) stated that by the year 2000, 16 countries still used classical biocontrol. Due to lack of quantitative data, a reliable estimate of the total area under classical biocontrol could not be made. The number of countries using augmentative biocontrol in this period had increased to 17 , with a total estimated area under augmentative biocontrol about 4,350,000 ha (see Table 1.1 in Chapter 1).

Information provided in the countryspecific chapters of this book shows that nowadays all forms of biocontrol and all types of biocontrol agents are applied in Latin America and the Caribbean (Table 32.1). The estimates for the number of countries with classical, augmentative and conservation biocontrol will be reliable. However, the number of countries with natural control (19) is underestimated, as many countries have not yet tried to document which potential pests are kept below densities causing damage. The area under augmentative biocontrol has strongly increased since 2000 and now exceeds 31 million hectares. The first estimate for classical biocontrol for Latin America and the Caribbean shows an area of more than 30 million hectares being protected.

In this chapter the achievements in biocontrol in Latin America and the Caribbean will be summarized. Next, the use of classical biocontrol in this region will be illustrated with data obtained from the BIOCAT databank (Cock et al., 2016). Then, factors limiting and stimulating biocontrol in the region will be presented and, finally, the future of biocontrol in the region is sketched based on remarks made in the country chapters.

\subsection{Achievements}

The major biocontrol activities during different periods for each of the Latin American and Caribbean countries are summarized in Table 32.2.

Table 32.2 provides information about similarities and differences in biocontrol approaches in various countries. The similarities concern the import and release of many of the same natural enemies in classical biocontrol projects during the early period of biocontrol in the region. Often, these natural enemies had been used successfully in Asia, Europe and North America and were introduced without additional research in Latin America and the Caribbean. Currently, area-wide biocontrol programmes aim at releasing the same natural enemies of several recently introduced invasive pests. These programmes are based on more

Table 32.1. Use of different forms of biological control and area under biocontrol in Latin America and the Caribbean.

No. of countries using biocontrol / area (ha) under biocontrol

\begin{tabular}{lcccc}
\cline { 2 - 4 } Period & Classical & Augmentative & Conservation & Natural \\
\hline $1895-1969$ & $16 / ?$ & $4 / ?$ & & \\
$1970-1999$ & $16 / ?$ & $17 / 4,350,000$ & & \\
$2000-2018$ & $29 / 30,747,889$ & $27 / 31,381,131$ & $13 / 447,114$ & $19 / 2,001,846$ \\
\hline
\end{tabular}


Table 32.2. Summary of achievements in biocontrol during three periods, with future plans and factors limiting and stimulating biocontrol for each Latin American and Caribbean country.

\begin{tabular}{|c|c|c|c|c|}
\hline Period 1800-1969 & Period 1970-1999 & 2000-now & Future & $\begin{array}{l}\text { Factors limiting and } \\
\text { stimulating biocontrol }\end{array}$ \\
\hline $\begin{array}{l}\text { Argentina: Many CBC } \\
\text { introductions; few ABC } \\
\text { projects; provider of } \\
\text { natural enemies, } \\
\text { particularly for weed } \\
\text { BC, with as major } \\
\text { success of control of } \\
\text { prickly pear in } \\
\text { Australia }\end{array}$ & $\begin{array}{l}\text { Many CBC introductions; few } \\
\text { ABC projects, few } \\
\text { successes; start of weed } \\
\text { BC research; important } \\
\text { provider of weed BC } \\
\text { agents }\end{array}$ & $\begin{array}{l}\text { Continuation of CBC of arthropods } \\
\text { in agriculture, forestry, and of } \\
\text { weeds; increase in ABC activities; } \\
\text { initiation of work on ConsBC; } \\
\text { important provider of weed } \\
\text { BC agents }\end{array}$ & $\begin{array}{l}\text { Anticipated increase of all } \\
\text { forms of } B C \text { in all areas of } \\
\text { agriculture, forestry and of } \\
\text { weed BC } \\
\text { Specific for Argentina: use } \\
\text { of weed CBC and provider } \\
\text { of weed BC agents }\end{array}$ & $\begin{array}{l}\text { Dominance of CC } \\
\text { Limited collaboration } \mathrm{BC} \\
\text { research and application; } \\
\text { limited development of } \\
\text { practical } \mathrm{BC} \text {; limited } \\
\text { funding for } \mathrm{BC} \\
\text { Good } B C \text { expertise available }\end{array}$ \\
\hline $\begin{array}{l}\text { Barbados: Many CBC } \\
\text { introductions, } \\
\text { successes in } \\
\text { sugarcane and citrus; } \\
\text { few ABC projects, } \\
\text { success in cotton; } \\
\text { provider of many BC } \\
\text { agents to other islands } \\
\text { in the region }\end{array}$ & $\begin{array}{l}\text { Several new CBC projects, } \\
\text { e.g. of pests in vegetables; } \\
\text { few ABC projects }\end{array}$ & $\begin{array}{l}\text { CBC in sugarcane and vegetables; } \\
\text { new CBC successes in palm } \\
\text { plantations, citrus orchards, and } \\
\text { of pink hibiscus mealybug on } \\
\text { various plants; } A B C \text { cotton; many } \\
\text { NC successes }\end{array}$ & $\begin{array}{l}\text { Anticipated increase in } B C \\
\text { activities due to new } \\
\text { invasive pests } \\
\text { Specific for Barbados: } \\
\text { documentation of } N C \text {, } \\
\text { large scale use of } C B C\end{array}$ & $\begin{array}{l}\text { Many new invasive species } \\
\text { Need for biocontrol of new } \\
\text { invasive pests }\end{array}$ \\
\hline $\begin{array}{l}\text { Belize: Several CBC } \\
\text { attempts without } \\
\text { success; documenta- } \\
\text { tion NC in sugarcane }\end{array}$ & $\begin{array}{l}\text { Several CBC attempts } \\
\text { without success }\end{array}$ & $\begin{array}{l}\text { Successes with } \mathrm{CBC} \text { of Asian citrus } \\
\text { psyllid and pink hibiscus } \\
\text { mealybug }\end{array}$ & $\begin{array}{l}\text { Continuation CBC pink hibiscus } \\
\text { mealybug and Asian citrus } \\
\text { psyllid; initiation of } A B C \text { with } \\
\text { microbials of pests in } \\
\text { sugarcane } \\
\text { Specific for Belize: use } \\
\text { of CBC }\end{array}$ & $\begin{array}{l}\text { Presence of international } \\
\text { institute OIRSA }\end{array}$ \\
\hline $\begin{array}{l}\text { Bolivia: Several } \\
\text { unsuccessful CBC } \\
\text { attempts; important } \\
\text { CBC success with } \\
\text { Rodolia cardinalis; } \\
\text { ABC of sugarcane } \\
\text { borers }\end{array}$ & $\begin{array}{l}\text { Several attempts with } C B C \\
\text { and } A B C ; \text { successes with } \\
\text { ABC in sugarcane, citrus, } \\
\text { potato storage, coffee; } \\
\text { documentation of } \\
\text { NC in several crops }\end{array}$ & $\begin{array}{l}\text { Successes with several large } A B C \\
\text { and CBC projects in citrus, coffee, } \\
\text { potato, sugarcane, quinoa, and } \\
\text { soybean; documentation of NC in } \\
\text { several crops }\end{array}$ & $\begin{array}{l}\text { Anticipated increase in } \\
\text { production and use of } \\
\text { local microbial agents; } \\
\text { documentation and use } \\
\text { of NC } \\
\text { Specific for Bolivia: } A B C \\
\text { with local microbials, } \\
\text { documentation of NC }\end{array}$ & $\begin{array}{l}\text { Dominance of } \mathrm{CC} \\
\text { Lack of funding for } \mathrm{BC} \text {, lack } \\
\text { of collaboration among } \mathrm{BC} \\
\text { experts, lack of education } \\
\text { in } \mathrm{BC} \text { and lack in transfer } \\
\text { of knowledge } \\
\text { Recent positive results in } \\
\text { BC projects }\end{array}$ \\
\hline
\end{tabular}




\begin{tabular}{l} 
Period 1800-1969 \\
\hline Brazil: Unsuccessful \\
attempts of CBC of \\
white peach scale, \\
coffee berry borer, \\
woolly apple aphid, \\
Mediterranean fruit fly \\
and oriental fruit moth; \\
successful CBC of \\
Rhodes grass scale; \\
ABC of sugarcane \\
borer with native \\
natural enemies; early \\
use of microbials for \\
pest and disease \\
control
\end{tabular}

Chile: Many successful early CBC projects, e.g. control of olive black scale, scales in citrus, avocado and other fruit, woolly apple aphid; use of $A B C$ with microbials to control coleopterans and lepidopterans in various crops; weed $\mathrm{BC}$; provider of $\mathrm{BC}$ agents
Period 1970-1999

2000-now

Future

Factors limiting and

stimulating biocontrol

Successful CBC of wheat aphids, cassava mealybug, citrus leaf miner, and Sirex woodwasp; ABC with natural enemies of citrus mealybugs, flies in poultry pens, fruit flies in vars fruit crops, lepidopterans in eucalyptus, and Sirex woodwasp in pine; $A B C$ with microbials of spittlebugs, soybean caterpillar, mate tree borer, and soil-borne diseases; large scale local production of arthropod and microbial ABCs

Successful CBC of wheat aphids, of the eucalyptus psyllid, and of weeds in various crops; $\mathrm{CBC}$ and $A B C$ of pine shoot moth; $A B C$ of diseases in fruit; prospecting for and commercialization of microbial agents and nematodes for $\mathrm{ABC}$ of coleopterans in various crops, and of pine shoot moth
$\mathrm{CBC}$ and $\mathrm{ABC}$ with natural enemies of pests in eucalyptus and pine. $A B C$ with natural enemies of lepidopteran pests in sugarcane, soybean, cotton, corn, beans, millet and tomatoes, of stink bugs in soybean, of spider mites, fungus gnats and thrips in cotton,

soybean, fruit orchards, ornamentals and vegetables, cotton

bollworm, Asian citrus psyllid, aphids, thrips, lepidopterans and spider mites in greenhouse crops, various scales in various crops. $A B C$ with microbials of pests in coffee, eucalyptus, pine, of mate tree borer, Asian citrus psyllid, soil nematodes in soybean, corn and coffee, rubber lace bug, cotton bollworm, fall army worm in corn, soil-borne diseases in many crops; prospecting for weed $\mathrm{BC}$ agents

$\mathrm{CBC}$ of walnut aphids, codling moth and woolly apple aphid in apple, wood wasps and eucalyptus weevil in forestry; attempts to use microbials for $A B C$ of lepidopterans and coleopterans in various crops and forestry; ABC of $T$. absoluta with predator, of diseases in various crops and forestry; development of technology transfer models; prospecting for and evaluation of microbial agents
Anticipated development of new $A B C$ projects with natural enemies and $A B C$ industry; development of more efficient $\mathrm{BC}$ agent shipment, release and monitoring methods; progress in technology transfer from research to application, improved collaboration and networking; development of ConsBC

Specific for Brazil: early and current large scale use of $A B C$ with natural enemies and microbials for pest and diseases; large scale local production of $B C$ agents, many $B C$ research projects

Continue prospecting for microbials for pest and disease control; improved formulations of $B C$ agents of diseases; improved monitoring and release of natural enemies; improved $\mathrm{BC}$ training of agricultural technicians

Specific for Chile: many early $C B C$ projects, $A B C$ with local microbials of pests and diseases, large scale prospecting for and production of microbials microbials; strong growth of production, quality control,
Dominance of $\mathrm{CC}$ industry Poor transfer of $\mathrm{BC}$ technology to farmer

Poor quality of non-registered $\mathrm{BC}$ products and with insufficient farmer guidance

Rich biodiversity as source for $B C$ agents

Good expertise in BC, many researchers

Large production units for $B C$ agents, strong private industry

International market demands for food with low pesticide residue levels

Improved BC agent registration procedures

Insufficient quality control of $\mathrm{BC}$ products

Access and Benefit Sharing regulations

Improved formulations for microbials

Presence of BioControl Technological Center

National and international pesticide regulations

Expertise in research and application of $B C$

Organic production for international market 
Colombia: Successful CBC of woolly apple aphid and cottony cushion scale; use of microbials to contro locusts
Costa Rica: Successfu $\mathrm{CBC}$ in citrus, coffee and sugarcane
$A B C$ of pests in cassava, cotton, maize, sorghum, soybean, sugarcane and tomato, in forestry, and in greenhouse vegetables and ornamentals; $\mathrm{CBC}$ and $A B C$ of coffee berry borer in coffee; use of microbials for $A B C$ of pests and diseases; prospecting, evaluation and production of microbials

$A B C$ in avocado, pineapple and cotton; $A B C$ and $C B C$ in sugarcane; $\mathrm{CBC}, \mathrm{ABC}$ and NC in citrus; ConsBC in palm plantations and in ornamental crops; NC of pests in banana, coffee, cashew, and timber; prospecting for and development of mass production of natural enemies and microbial agents
Documentation of NC in cassava; FBC and $\mathrm{CBC}$ of Columbian fluted scale; ConsBC in sugarcane, chilli pepper, oil palm, coffee and ornamentals; $A B C$ of pests in cassava, citrus (e.g. Asian citrus psyllid), coffee (coffee berry borer), cotton, maize, oil palm, greenhouse vegetables and ornamentals, potato, sorghum, sugarcane, rice, and forestry, of flies in livestock production and vectors of human diseases; prospecting, evaluation and production of microbials

Start of CBC of Asian citrus psyllid ConsBC and $A B C$ in palm plantations; $C B C$ with $A B C, N C$ and ConsBC in citrus, coffee and sugarcane; $\mathrm{NC}$ and $\mathrm{ABC}$ in banana; prospecting for natural enemies and microbial agents
Anticipated production and use of entomopathogenic nematodes for root bore control, improved formulation technology for Trichoderma, development of quality control of $B C$ agents.

Specific for Colombia: ABC projects, many BC activities in greenhouse ornamentals; prospecting for and production of microbials; use of ConsBC

Anticipated improved and increased local production and use of microbials; improved quality control methods for BC agents

Specific for Costa Rica: ABC with local microbials, large scale prospecting, documentation of NC, use of ConsBC
Dominance of CC industry Complicated national

legislation for import of exotic BCs

Access and Benefit Sharing regulations

Poor quality of unregistered $\mathrm{BC}$ products

Expertise in research and application of $B C$

Good infrastructure and several centres for $B C$ research

Local production of $B C$ agents

Compulsory use of some forms of $B C$

Aggressiveness of $\mathrm{CC}$ Poor quality of local BC products

Use of organic agriculture

Export demands for agricultural products

Establishment of national programme for $B C$ 
\begin{tabular}{l} 
Period 1800-1969 \\
\hline $\begin{array}{c}\text { Cuba: Successful CBC } \\
\text { of citrus blackfly with }\end{array}$
\end{tabular}

parasitoid; $A B C$ of

sugarcane borer with

native parasitoid
Dominica: Several

unsuccessful CBC

projects in citrus,

banana, coffee,

vegetables; successful

CBC of sugarcane

borers

Dominican Republic:

CBC with coccinellids,

e.g. Cryptolaemus and

Rodolia, for control of

cottony cushion scale;

introduction of

mongoose for rat

control and toads for

pests in sugarcane;

documentation of

fungal pathogens of

weeds

Period 1970-1999

2000-now

Future

Factors limiting and

stimulating biocontrol

$A B C$ of many pests and several diseases in many crops with predators,

parasitoids and microbial agents; ConsBC of sweet potato weevil with predatory ants; creation of hundreds of centres for mass production of entomophagous species; prospecting for microbial control agents

Successful CBC of citrus blackfly; unsuccessful $A B C$ of diamondback moths and armyworms in various crops

$A B C$ of sugarcane pests, of whitefly in vegetables, of coffee berry borer and of rice stalk stink bug; $\mathrm{CBC}$, $A B C$ and $N C$ of citrus pests, CBC of vector transmitting snails; testing and use of microbials; testing of weed $\mathrm{BC}$; prospecting for and mass rearing of natural enemies
ABC with Trichogramma spp. of various lepidopterans in several crops; study and large scale use of ConsBC; local production of parasitoids, predators, entomopathogenic nematodes and fungi, nematopathogenic fungi and bacteria, and phytopathogenic fungi; strong governmental support for BC

Continuation of successful CBC programmes in citrus and

sugarcane

\section{CBC of papaya mealybug, pink} hibiscus mealybug, Anastrepha fruit flies, and pigeon pea pod fly; $\mathrm{NC}$ of diamondback moth, red palm mite and other mites, many pests of oriental vegetables, and of exotic pests in Ficus and Cycas; $\mathrm{NC}$ and ConsBC of pests in organic fruit and coffee; $A B C$ with microbials
Continued support for development of new contro agents, for better formulations of microbial control agents, and for more efficient production to replace imported products. Increase use of ConsBC

\section{Specific for Cuba: ConsBC,}

many local centres for

mass production of $B C$ agents.

Anticipated increased funding for BC by the Ministry of Agriculture; increased field testing of BC within IPM projects

Specific for the Dominican Republic: prospecting, demonstration of NC
Awareness among farmers and community of contribution of $B C$ to economy, ecology, environment and society

Strong governmental support for $B C$

Many local centers for production of $B C$ agents Appreciation / broad use of $B C$ by farmers

Lack of resources for BC research and application, lack of expertise in BC

Dominance of CC

Export demands for products without pesticides

Organic production, GAP labels 
Ecuador: CBC of woolly apple aphid in apple, Icerya sp., purple scale, and citrus blackfly in citrus, and of sugarcane borer in sugarcane

\section{EI Salvador}

\section{French Guiana,}

Guadeloupe and

\section{Martinique:}

Successful CBC of sugarcane borers
CBC of cottony cushion scale and citrus leaf miner in citrus, of white rice borer in rice, of coffee berry borer in coffee, of white mango scale in mango; $A B C$ of leafhoppers in sugarcane, of soil-borne pests in vegetables, of lepidopteran pests in maize, soybean, sugarcane, banana and cotton; prospecting for natural enemies of whiteflies, and of Tuta absoluta

$\mathrm{NC}$ in fruit trees and coconut palm; $\mathrm{CBC}$ and $\mathrm{FBC}$ in citrus; NC and $\mathrm{CBC}$ in cotton, corn and bean; $A B C$ of lepidopterans and mosquitos; prospecting for nematophagous fungi

Successful CBC of sugarcane Successful CBC of sugarcane

borers, pink hibiscus mealybug, Asian citrus psyllid, and citrus blackfly; first attempts at CBC of fruit flies
CBC of citrus leaf miner, fruit flies in tropical fruit and scales in mango. CBC of cottony cushion scale on the Galapagos islands; $A B C$ of pests in banana, of soil-borne pests and diseases in broccoli, pod rot disease in cacao, diseases and pests in oil palm, rice, pineapple, in ornamentals and vegetables in greenhouses, of diseases in papaya, and of pests in sugarcane; prospecting for $\mathrm{BC}$ agents, including entomopathogenic fungi and nematodes; improvement of formulations of microbial control agents

Microbial control of soil diseases, and of lepidopterans, coleopterans and nematodes in several crops; control of mosquitos with tilapia fish

\section{borers, pink hibiscus mealybug,} Asian citrus psyllid, and citrus blackfly; $A B C$ in vegetable crops; prospecting for and use of natural enemies in ConsBC in various crops
Continued governmental support for local training and production of BC agents Regulation for and registration of $\mathrm{BC}$ agents Increase of $\mathrm{CBC}$ of invasive weeds and insects, and of $A B C$ of agricultural pests on the Galapagos islands

Specific for Ecuador: many $C B C$ and $A B C$ projects, disease $B C$ in many crops; $B C$ of invasive species in natural ecosystems; prospecting for $B C$ agents

\section{Specific for EI Salvador:} demonstration of NC in several crops

Anticipated studies on new exotic species for CBC of mango mealybug, and for improved ABC of the Asian citrus psyllid

Specific for French

territories: prospecting and use of ConsBC
Governmental infrastructure $B C$ research, training and extension, prospecting for $B C$ agents, and collection of $B C$ agents

Governmental, private national and international producers of $B C$ agents

Demand for pesticideresidue free food by farmers, consumers and the international market 
Table 32.2. Continued.

\begin{tabular}{|c|c|c|}
\hline Period 1800-1969 & Period 1970-1999 & 2000-now \\
\hline Guatemala & $\begin{array}{l}\text { ABC of lepidopterans in } \\
\text { cotton, corn and } \\
\text { vegetables, of coffee berry } \\
\text { borer and nematodes in } \\
\text { coffee; } \mathrm{CBC} \text { of citrus }\end{array}$ & $\begin{array}{l}\mathrm{NC} \text { and } \mathrm{ABC} \text { in coffee; } \mathrm{CBC} \text { of } \\
\text { fruit flies; } \mathrm{ABC} \text { in cotton; } \mathrm{ABC} \\
\text { of vector of malaria with } \\
\text { microbials; testing of microbials } \\
\text { against spittle bugs in pastures }\end{array}$ \\
\hline
\end{tabular}

blackfly

Guyana: Successful CBC of sugarcane borer, and ConsBC of lepidopteran in rice; prospecting for natural enemies of various pests

Haiti: Partial successful CBC of sugarcane borer, successful CBC citrus blackfly

Honduras: Prospecting for $\mathrm{BC}$ agents

$\mathrm{CBC}$ in sugarcane; $\mathrm{CBC}$ attempts for control of fruit fly; $A B C$ in palm; $A B C$ attempts for control of red palm mite; ConsBC of rice pests

Successful CBC of pink hibiscus mealybug; prospecting for natural enemies

$A B C$ with microbials in various
Successful ABC of lepidopteran in palm, and $\mathrm{CBC}$ of hibiscus mealybug

Attempts for CBC of coffee berry borer

CBC of weed; CBC attempts for control of lepidopterans in various crops; $A B C$ of lepidopterans, whiteflies; microbial control of lepidopterans; ConsBC in various crops; creation of teaching and research Center for Biological

Control in Central America; large scale prospecting
Factors limiting and stimulating biocontrol

Future

Few BC experts, limited

Anticipated start with $\mathrm{CBC}$ of funding, expensive Asian citrus psyllid

Specific for Guatemala:

IPM including NC and $A B C$ of coffee pests registration of $\mathrm{BC}$ agents

Export demands for agricultural products Health risks of pesticides for workers and consumers

Positive experiences with $B C$

Continued studies for $\mathrm{ABC}$ of red palm mite

Specific for Guyana:

prospecting and

ConsBC crops; mass production of natural enemies (including nematodes) for $A B C$ in vegetables, sweet potato, coffee berry borer, plantain; training of many BSc students; development and production of microbial control agents for disease and pest control
Continued studies of CBC of fluted scale in peanuts and other crops

Continued positive attitude towards $\mathrm{BC}$, and training and production facilities Specific for Honduras: prospecting, teaching and research in $B C$, development and production of microbial agents for disease and pest control
Lack of finances for CC towards $B C$

Good training facilities Good local production facilities for $B C$ agents
Positive attitude 
Jamaica: $C B C$ of rats, citrus black fly, banana weevil, cocoa thrips, various other pests and weeds; NC and $\mathrm{CBC}$ of sugarcane and coconut pests; provider of $\mathrm{BC}$ agents

Mexico: Many successful early CBC projects in alfalfa, apple,

banana, bean, citrus, cotton, mango,

sugarcane; $A B C$ in pastures and sugarcane; construction of mass production centres for natural enemies in the 1960s

Nicaragua: $A B C$ of pests in cotton; prospecting
$\mathrm{CBC}$ attempts for control of fruit flies; NC and CBC of sugarcane borer, of lepidopterans in cruciferous crops and of pine mites;

$\mathrm{ABC}$ of sweet potato weevil; NC of whiteflies and coffee leaf miner, NC and $A B C$ of citrus root weevils and of coffee berry borer; prospecting

CBC in citrus, coffee, corn, cotton, fruit, forest, potatoes, and of water hyacinth; $A B C$ of pests in coffee, cotton, cruciferous crops, fruit, forest, sorghum, sugarcane, vegetables and ornamentals; construction of 20 regional centres for mass rearing of natural enemies and entomopathogenic fungi; 65 private insectaries

IPM in cotton; BC studies of pests in cotton and citrus; studies of microbials for control of mosquitos; mass production of Chrysoperla and Trichogramma, and microbial agents; $A B C$ attempts to control diamondback moth
$\mathrm{NC}$ and $\mathrm{CBC}$ of brown citrus aphid, $\mathrm{NC}$ of false Colorado beetle in gully bean, ensign scale in various crops, of lime swallow tail, of red palm mite; $\mathrm{CBC}$ of pink hibiscus mealybug; $N C$ and $A B C$ of citrus root weevil; NC and FBC of papaya mealybug; $A B C$ and $F B C$ of Asian citrus psyllid; $A B C$ of coffee berry borer, sweet potato weevil, and beet armyworm

$\mathrm{BC}$ of many hemipteran pests. CBC in citrus, corn, cotton, eucalyptus, mango, strawberry and of weeds in water; $A B C$ in citrus, corn, cotton, cruciferous crops, fruit, grape, ornamentals vegetables (field and greenhouses), sorghum, soybean, and sugarcane, weeds in wetlands, and grasshoppers; mass production of 40 species of $B C$ agent in 65 laboratories

ABC of whiteflies, aphids and pests in sugarcane; CBC of Asian citrus psyllid; construction of biofactories for mass production of Trichogramma and native Orius spp.; prospecting
Anticipated reduction in use of high risk pesticides necessitates construction of new BC facility; development of ConsBC; new invasive pest are targets for $\mathrm{BC}$

Specific for Jamaica: early and recent $C B C$ successes, documentation many NC cases, prospecting

Development of risk scenarios for more than 1200, pests; development of $\mathrm{BC}$ for new pests and diseases, e.g. laurel ambrosia beetle, Drosophila suzukii; increase in use of BC; promotion of use of eco-friendly products

Specific for Mexico: many $A B C$ and $C B C$ successes, good infrastructure for research and application of $B C$, risk scenarios for new pests, pro-active

\section{development of $B C$}

Anticipated production of entomopathogens

\section{Specific for Nicaragua:} prospecting, local mass production of $B C$ agents
Agriculture still highly dependent on pesticides

Increased registration of lower risk class pesticides, including biopesticides.

Available expertise, infrastructure and funding for $B C$ research and application

New invasive pest offer possibilities for $B C$

Good governmental infrastructure and support for research, production and application of $B C$

Risk scenarios for new pests and diseases, development of $B C$ for new pests and diseases

Specific pesticide residue requirements for export markets

Dominance of CC

Poor selling and logistic mechanism for $\mathrm{BC}$ agents Local production of $B C$ agents 
Table 32.2. Continued.

$\begin{array}{ll}\begin{array}{l}\text { Period 1800-1969 } \\ \begin{array}{l}\text { Panama: CBC of citrus } \\ \text { blackfly }\end{array}\end{array} & \begin{array}{c}\text { ABC of sugarcane borer and } \\ \text { diamond back moth; } \\ \text { prospecting }\end{array} \\ \text { Paraguay } & \begin{array}{l}\text { ABC of soybean caterpillar } \\ \text { with baculovirus, and } \\ \text { sugarcane borer with } \\ \text { parasitoids }\end{array}\end{array}$

Peru: CBC woolly apple aphid in apple, cottony white scale in cotton, hemispheric scale and olive blackfly in olive, cottony cushion scale, purple scale, Florida red scale and aphids in citrus; $A B C$ of cotton aphid and tobacco budworm in cotton, and sugarcane borer in sugarcane; $\mathrm{NC}$ of pests in several crops; creation of centre for introduction and rearing of useful insects
CBC of West Indian red scale, citrus woolly whitefly, and citrus leaf miner in citrus, alfalfa green aphid in alfalfa, blue psyllid in eucalyptus; $A B C$ of sugarcane borers in sugarcane, fruit flies in fruit, pink bollworm in cotton, and house flies; development of $\mathrm{BC}$ of diseases; increased role of governmental centre for research and application of $\mathrm{BC}$; creation of private $\mathrm{BC}$ agent production

laboratories; governmental financial support to reduce negative impacts of $\mathrm{CC}$

2000-now

Future

Factors limiting and stimulating biocontrol

CBC of coffee berry borer, ConsBC of thrips in cucurbits and lepidopterans in rice; prospecting, production and application of microbial control agents and natural enemies

ConsBC in several crops; $A B C$ with locally produced microbials in various crops for pest and disease control; large scale prospecting for predators, parasitoids and microbial control agents

Many ABC projects for control of pests in cotton, sugarcane, asparagus, avocado, olive, pomegranate, forest, coffee, cacao, vine, vegetables, and quinoa; continued strong role of governmental centre for research, mass production and application of $\mathrm{BC}$; production of many predators, parasitoids, entomopathogenic and antagonistic agents in network of regional laboratories; large collection of microbial agents; agro-exporting companies with high demand for $\mathrm{BC}$ demonstration that $B C$ is considerably cheaper than CC and prevents secondary pests
Anticipated development of

artificial media to economize mass rearing of natural enemies

Specific for Panama

\section{prospecting}

Specific for Paraguay: large scale prospecting, local mass production of microbial control agents

Increase in certification of pesticide free food; governmental agreements with association of citrus farmers to use $\mathrm{BC}$, with association of asparagus farmers and large private exporting companies to use IPM, including $\mathrm{BC}$; development of ConsBC

Specific for Peru: strong governmental support and infrastructure for $B C$; many $C B C$ and $A B C$ projects; certification of food produced under BC
Dominance of cheap CC

Limited governmental support for BC

Production of organic food

Pesticide resistance against important pests

Appreciation of pesticide free food

Early and continuous governmental infrastructure for research and mass rearing of $B C$ agents

Private production labs supported by governmental center for BC

Governmental financial support to reduce impacts of CC

Large agro-exporting companies with high demand for $B C$

Demonstration that $B C$ is cheaper than $C C$ and prevents secondary pests Certification of pesticide free products 
Puerto Rico: NC and $\mathrm{CBC}$ of several pests in sugarcane; $\mathrm{CBC}$ in citrus and coffee

Remaining Caribbean Islands: Many

unsuccessful CBC

releases; CBC

successes of pests

in arrowroot, citrus,

coconut, cotton,

sugarcane, and prickly

pear and puncture

vine weeds; ConsBC

of cotton leafworm in

cotton, of white grub

larvae in sugarcane,

and arrowroot leaf

roller in arrowroot

$A B C$ of sugarcane

borers in sugarcane;

demonstration of

NC of West Indian

cane fly in

sugarcane

Suriname: Prospecting and identification of

natural enemies

responsible for $\mathrm{NC}$ of

several pests
$\mathrm{CBC}$ of water weeds; NC,

$\mathrm{FBC}$ and $\mathrm{CBC}$ of several

pests in citrus, sugarcane,

of melon worms in

cucurbits, of pink hibiscus

mealybug and papaya

mealybug; ConsBC of

pests in coffee

$\mathrm{CBC}$ of cottony cushion scale and citrus blackfly

in citrus, and of coconut mealybug and coconut

scale in coconuts;

reduction in $\mathrm{CBC}$

attempts since 1980

\section{Attempts of $A B C$ with} nematodes; demonstration of NC of coconut pests, green cassava mite and Pomacea snails; prospecting
FBC of Asian citrus psyllid; development of $\mathrm{CBC}$ of Harrisia cactus mealybug; NC, ABC and ConsBC of coffee berry borer

Successful region wide CBC programmes for control of the pink hibiscus mealybug and the papaya mealybug; demonstration of NC of the coconut whitefly and the passion vine mealybug; use of FAO Code of Conduct for the Import and Release of Exotic Biological

Control Agents; implementation of Farmers Field Schools to enable farmers to use IPM and become less dependent on $\mathrm{CC}$

$\mathrm{CBC}$ of pink hibiscus mealybug; research on $\mathrm{BC}$ of Carambola fruit fly; prospecting efforts to control Carambola fruit fly. Specific for

Suriname: prospecting, documentation of NC
Good infrastructure for $B C$ research

Organic and

environmentally-friendly agriculture stimulate research in $B C$

Specific for Puerto Rico:

CBC successes, documen-

tation of NC, ConsBC

Continuation of Farmer Field

Schools; increased role of

implementation of region-wide

BC programmes

Specific for the Remaining

Caribbean islands: many

early CBC projects, recent

region-wide collaboration

resulting in $C B C$

successes

Many small islands with small and diverse crop

areas

Many new invasive pests

Limited extension service

Domination of CC industry

Presence of several

region-wide organizations assisting in development of $B C$

Implementation of Farmer

Field Schools 


\begin{tabular}{l} 
Period 1800-1969 \\
\hline Trinidad and Tobago: \\
CBC of various pests, \\
ConsBC with birds \\
and insects for control \\
of sugarcane pests, \\
ABC with predator \\
and microbial to \\
control sugarcane \\
froghopper; important \\
provider of BC agents \\
in the region \\
Uruguay: Successful
\end{tabular}

Uruguay: Successful CBC of white peach scale, cottony cushion scale, woolly apple aphid, San Jose scale, eucalyptus weevil; unsuccessful ABC with entomopathogens; prospecting for native natural enemies; provider of natural enemies for the region

Period 1970-1999

2000-now

Future

Factors limiting and

stimulating biocontrol

Successful $A B C$ and $C B C$ of sugarcane pests; unsuccessful $\mathrm{CBC}$ of cabbage pests; important provider of $\mathrm{BC}$ agents for the region

$A B C$ of lepidopterans in sugarcane, vine and cotton with Trichogramma, of pine wood wasp with nematodes, of the sunflower caterpillar and the soybean caterpillar with viruses; prospecting for native $B C$ agents including microbials
Successful CBC of citrus blackfly and pink hibiscus mealybug

Increase of accidental import

$\mathrm{CBC}$ in eucalyptus and pine; $\mathrm{CBC}$ attempts in citrus; $A B C$ in vegetables and soybean. Start of centre for forest research, including $B C$; research of $A B C$ with parasitoids and microbials of stinkbugs; development of ConsBC in soybean and sorghum of exotic pests creates need for BC

Specific for Trinidad and Tobago: good BC research infrastructure, important provider of $B C$ agents in the region

Consumer appreciation for food with low pesticide residues

Good BC research infrastructure

$B C$ appreciated by farmers

Start of mandatory registration for BC agents; creation of centre for collection and storage of microbials; increase in $A B C$ of diseases

Specific for Uruguay: many early and current $C B C$ successes in fruit orchards and forestry, prospecting
Farmers adhere to low price CC

Insufficient BC agents available

Well established research and application network for $B C$

Consumer concern about CC

Demands for residue-free food for export 
Venezuela: Several CBC attempts in various crops; successful ABC of sugarcane borer mass production of Lydella
Successful CBC of citrus blackfly; $A B C$ of sugarcane borers with parasitoids and nematodes; improved mass production of Lydella,

Trichogramma mass rearing for ABC of lepidopteran

pests, and Metarhizium for froghopper control; development of IPM for many crops, including mass rearing of natural enemies for $\mathrm{ABC}$ by private company
$\mathrm{CBC}$ in citrus; continuation of $\mathrm{ABC}$ research of sugarcane pests; establishment of network of 19 regional laboratories producing $\mathrm{BC}$ agents and promoting agro-ecological production methods resulting in application of $\mathrm{ABC}$ in many crops; prospecting and study of $B C$ potential of $B C$ agents including antagonists for disease control
New laws promoting

sustainable agriculture

Specific for Venezuela: many

$A B C$ projects; research

on Trichogramma;

prospecting; testing

and use of disease

antagonists; network

of BC laboratories
Lack of transfer of

knowledge from research

to application

Shortage of chemical pesticides

Laws promoting sustainable agriculture

Network of BC laboratories

Abbreviations: $\mathrm{ABC}=$ augmentative biocontrol, $\mathrm{BC}=$ biocontrol, $\mathrm{CBC}=$ classical biocontrol, $\mathrm{CC}=$ chemical control, $\mathrm{ConsBC}=$ conservation biocontrol, $\mathrm{FBC}=$ fortuitous biocontrol

$\mathrm{NC}=$ natural control 
extensive local research and involve pre-release risk evaluations, as well post-release assessment of the effect of introductions.

\subsubsection{Examples of early use of the same natural enemies in many countries in the region}

From 1900, a number of natural enemies were introduced into Latin America and the Caribbean and resulted in permanent, classical biocontrol of important pests. Notable examples are as follows.

- Importation from various sources of the parasitoids Aphytis diaspidis (How), Aphytis fuscipennis (How), Encarsia (= Prospaltella) berlesei How, Aspidiotiphagus citrinus (Crwf), Arrhenophagus chionaspidis Auriv. and the predator Scymnus sp. into Peru in 1904 for control of the cotton white scale Pinnaspis strachani Ferris and Rao. Later, these natural enemies were used in several other countries for control of similar pests in various crops.

- The predator Cryptolaemus montrouzieri Mulsant was imported into Puerto Rico from the USA in 1912 to control mealybugs in sugarcane. This predator was later introduced from the USA or from a regional country into many other Caribbean and Latin American countries for control of various pests in various crops.

- Introduction of E. berlesei from Italy into Uruguay in 1913 for control of white peach scale $P$. pentagona. The parasitoid was then sent from Uruguay to other Latin American countries.

- The predator R. cardinalis, native from Australia, imported into Uruguay in 1919 from France for control of cottony cushion scale I. purchasi. The predator was then introduced into other Latin American countries and the Caribbean, but later obtained from other sources as well.

- Importation of the parasitoid A. mali from the USA into Uruguay in 1921 for control of woolly apple aphid E. lanigerum and later introduced from Uruguay into other countries in Latin America.

- Introduction of the predator Chilocorus bivulnerus (Mulsant) from the USA into
Uruguay in 1924 for control of San José scale Comstockaspis perniciosus (Comstock). The predator was later introduced from Uruguay into other countries in Latin America, but was on other occasions introduced from the USA as well.

- The parasitoids E. serius, Encarsia opulenta (Silv.), A. hesperidum and Encarsia perplexa Huang and Polaszek were imported from India into Cuba in 1930 for control of citrus blackfly $A$. woglumi. One or more of these species were then exported in 1930 to Costa Rica, Haiti and Jamaica and in 1931 to the Bahamas and Panama. Later, one or more of these species of parasitoids were introduced into other countries in the region.

- The predator Cryptolaemus montrouzieri and the parasitoid Leptomastidea abnormis (Girault) were introduced in 1931 into Chile from the USA for control of Planococcus citri (Risso).

- Importation of the parasitoid Metaphycus helvolus (Compere) in 1931 into Chile from the USA to control olive black scale Saissetia oleae (Olivier). The parasitoid was introduced into several other Latin American countries for control of olive black scale or other scale species.

- Introduction of the pyralid herbivore Cactoblastis cactorum (Berg) originating from Argentina into Nevis in 1957 for control of Opuntia spp. cacti, then released in Antigua, the Cayman Islands and Montserrat. It later spread naturally to other islands in the Caribbean, including the Bahamas.

- A special case is that of the biocontrol of sugarcane borers, Diatraea spp. Initially several tachinid parasitoids native to Latin America and the Caribbean were found (Lixophaga diatraeae (Tns.) and Lydella minense Tns.). Natural control of sugarcane borers by L. diatraeae parasitoids was documented as early as 1930 in Jamaica and later in Cuba. Also in Puerto Rico the important role of natural control of borers by native natural enemies was demonstrated, in this case by three native parasitoids Trichogramma minutum Riley, Tetrastichus haitiensis Gahan and L. diatraeae. L. minense was originally found in the Amazon area of Brazil and introduced into Guyana in 1932, where it reduced sugarcane borer 
populations. The tachinid parasitoid species were redistributed over the region, often resulting in establishment and reduction in borer numbers. Later, in the 1950s, mass rearing and augmentative releases of native tachinids were initiated in Cuba, a practice followed by other countries in the region. In this period, extensive trials were made with inundative releases of native Trichogramma spp., e.g. in Barbados and Guyana. Since 1950, a number of exotic stem borer parasitoids have been imported from Africa and Asia by CABI into Trinidad and Tobago, and one of these, Cotesia flavipes (Cam.) originating from Asia, has been particularly successful in borer control. This parasitoid has been distributed to most countries in the region that face sugarcane borer problems and is currently released augmentatively on millions of hectares of sugarcane (see e.g. Chapter 6: Brazil).

\subsubsection{Recent examples of use of the same natural enemies in the region}

In the Caribbean and Central America, several area-wide biocontrol projects have recently been realized or are in the implementation phase. The natural enemies used in these projects are also used in a number of Central and South American countries. Examples of these projects are as follows.

- Introduction of the parasitoid Anagyrus kamali Moursi from China and the predators C. montrouzieri and Scymnus coccivora Aiyyar from India for control of the pink hibiscus mealybug Maconellicoccus hirsutus (Green). This mealybug, native to Asia, was accidentally introduced into Grenada in 1994, then into Trinidad and Tobago in 1995, and next into other locations in the Caribbean and South, Central and North America. Parasitoids and predators were shipped from Trinidad and Tobago to many countries in the region. Classical biocontrol of the pink hibiscus mealybug is considered one of the highlights of recent biocontrol.

- Importation and release of the parasitoids Anagyrus loecki Noyes and Menezes, Acerophagous papaya Noyes and Schauff and
Pseudleptomastrix mexicana Noyes and Schauff for control of papaya mealybug Paracoccus marginatus Williams and Granara de Willink. This pest originates from Mexico and was first detected in the Caribbean in 1993. Natural enemies are reared at the USDA APHIS parasitoid-rearing facility in Puerto Rico (see Chapter 26: Puerto Rico), among other locations, and have been introduced with success into many countries in the region.

- Introduction of Tamarixia radiata Waterston, native to Asia, for control of the Asian citrus psyllid, Diaphorina citri Kuwayama. This pest is native to southern Asia and is a vector of the currently most serious citrus disease worldwide, referred to as citrus greening or huanglongbing. The parasitoid has been imported into and is mass reared in many countries in the region and has successfully reduced citrus psyllid populations.

- Natural control of the red palm mite Raoiella indica Hirst. This pest is native to Asia; it was accidentally introduced into the Caribbean in 2004 and now also occurs in South America. Barbados, the Dominican Republic and Jamaica, among others, have documented the role of native organisms (a predatory mite, coccinellid and neuropteran predators and acaropathogenic fungi) in reduction of this pest (see countryspecific chapters).

\subsubsection{Differences in use of biocontrol in the region}

Although there are many similarities in biocontrol programmes applied throughout the region, there are also a number of interesting differences, which are summarized below and become obvious when looking at Table 32.2.

\section{Classical biological control}

In the early period of biocontrol up to 1970 , many countries in the region imported natural enemies that had been shown to be successful in other areas of the world. Some countries have been relatively inactive in classical biocontrol, e.g. Cuba, Dominica, French territories and Suriname. From 1970 to 1999, import of 
natural enemies for classical biocontrol strongly decreased in many countries, with the exception of Argentina, Mexico, Peru, the Caribbean and Venezuela (see Section 32.3 for details). Currently, classical biocontrol is documented as being used in all countries in the region, with the exception of Paraguay.

\section{Augmentative biological control}

Only a few countries were involved in augmentative biocontrol in the early period. Brazil, Chile, Colombia, Cuba, Mexico and Peru played a major role during this time and were using arthropod natural enemies as well as microbial control agents. Many countries started with a few augmentative biocontrol projects during the period 1970-1999. The countries that applied a lot of augmentative biocontrol in the early period continued to do so, with Ecuador as a new country with many new projects. The spectrum of biocontrol agents used showed an impressive growth in diversity. Also, the area on which augmentative biocontrol of pests, and in particular control of diseases, was applied strongly increased. Many countries started to mass produce biocontrol agents. Currently, augmentative biocontrol is used in most countries in the region, but is limited in others (e.g. El Salvador, Paraguay and Suriname) and not used in Belize and a number of Caribbean islands. Local mass production of biocontrol agents for pest and disease control occurs in many countries.

\section{Conservation biological control}

Large differences exist among countries in the use of conservation biocontrol. Early application of conservation biocontrol by promoting the presence of beneficial birds, lizards and arthropods took place in Guyana and on a number of Caribbean islands (see country-specific chapters). During the period 1970-1999, particularly Cuba developed important conservation biocontrol projects, and also Costa Rica, Honduras and Puerto Rico started to use this form of biocontrol in several crops. Currently, Colombia, the Dominican Republic, French islands, Panama, Paraguay and Uruguay also use conservation biocontrol, in addition to the countries that started with this type of biocontrol in previous periods. Still, quite a large number of countries in the region do not study or apply conservation biocontrol.

\section{Natural control}

Early documentation of natural control of pests in sugarcane was reported by Belize, Jamaica, Puerto Rico and the Remaining Caribbean islands, and for several other pests in various crops in Peru and Suriname (see country-specific chapters). In the period 1970-1999, the following additional countries documented cases of natural control for a number of pests in different crops: Bolivia, Costa Rica, El Salvador. Recently, several other Caribbean islands and Colombia documented natural control.

\section{Biological control of weeds}

Many aquatic and terrestrial weeds that are at present found throughout the world originated in the Neotropical region. Also, a number of the most successful examples of biological weed control involve species that originated in this region, but only a few countries have been playing a role in weed biocontrol research. In Latin America, Argentina has been an important provider of weed biocontrol agents since 1899 , when a phytophagous coleopteran was sent to the USA for control of snake weed, followed by many other agents for control of weeds all over the world (see Chapter 2: Argentina). In the Caribbean, Trinidad and Tobago have been an important source of weed biocontrol agents (see Chapter 29: Trinidad and Tobago; and Cock, 1985). Today, biocontrol of weeds in the region is applied in only Argentina, Chile, Honduras, Mexico and Puerto Rico, but it is studied in Brazil, Ecuador (Galapagos) and Suriname, among others.

\section{Biological control of pests in forests}

Relatively few countries use biocontrol in forestry. Uruguay is a pioneer country in forest pest biocontrol and currently also Argentina, Brazil, Chile, Colombia, Mexico and Peru apply biocontrol agents to control pests in forests.

\section{Biological control in natural areas}

Only the chapters for Chile and Ecuador mention projects about biocontrol in natural areas. 
In Chile (Chapter 7), two weed species have been brought under classical biocontrol in nature: phytophagous Chrysolina hyperici (Foster) beetles have been released for control of St John's wort Hypericum perforatum L.; and the phytopathogen Phragmidium violaceum (Schulz) Winter was applied for control of the weedy shrub Rubus ulmifolius (Schott.). On the Galapagos islands in Ecuador (Chapter 13), the invasive cottony cushion scale I. purchasi, which was seriously affecting threatened endemic plant species, was successfully controlled by the predator R. cardinalis. The success of this programme resulted in ideas for biocontrol of other invasive plant and insect species in the Galapagos islands.

\subsubsection{Developments of particular interest in Latin America and the Caribbean}

\section{Early and continued large-scale prospecting for natural enemies, pathogens and antagonists for pest, disease and weed control}

Prospecting for biocontrol agents started before 1900 and the first biocontrol agent was exported from the region in 1899 (see Chapter 2: Argentina). After identification of many arthropod natural enemies, a large number of microbial agents were isolated. The many prospecting projects resulted in: (i) documentation of natural control; (ii) development of conservation biocontrol; (iii) identification of biocontrol agents that could be used in augmentative and classical biocontrol within and outside the region; and (iv) local large-scale mass production of arthropod natural enemies, pathogens and antagonists.

\section{Early and continued documentation of natural control and use of conservation biocontrol}

In Section 32.2.3, the use of natural and conservation biocontrol was summarized. Compared with other world regions, the documentation and use of these two activities started early and is used in a growing number of countries in this region. Some interesting early examples, with more information in the country-specific chapters, are as follows.

- Use of the native parasitoid Scelio famelicus Riley for control of the migratory locust Schistocerca paranensis (Burmeister) in Venezuela in 1884.

- Demonstration of natural control of the sugarcane borer Diatraea saccharalis Fabricius by Apanteles sp. and Euplectrus sp. in Puerto Rico in 1895; realization of the importance of birds, lizards and other reptiles to reduce pests.

- Demonstration of the role of predacious birds for control of the giant moth borer Telchin licus (Drury) (= Castnia licoides (Boisduval)) in sugarcane in Trinidad in the early 1900s. Construction of bird roosts and planting of bamboo clumps to encourage birds close to sugarcane fields. Use of plants as nectar sources for attracting arthropod natural enemies and the construction of predatory wasp shelters close to crops.

- Use of the native Jack Spaniard wasp Polistes cinctus cinctus Lepeletier, predator of the cotton leaf worm Alabama argillacea (Hb.) and other pests in St Vincent since 1910, and later on other Caribbean islands. Populations of the wasp have been encouraged in the Caribbean by the construction of shelters near the cotton fields under which they can nest.

- Demonstration of effectiveness of insectivorous birds in reduction of Spodoptera frugiperda Smith populations in rice nurseries in Guyana in the 1910s, in particular when erecting perches in the fields for birds to sit on.

- Demonstration of epizootics in populations of the grasshopper Schistocerca americana (Drury) caused by the native entomopathogenic bacterium Coccobacillus acridiorum D'Herelle in Mexico in 1911. Shortly after this observation, the bacterium was used in Argentina and Colombia to cause epizootics in grasshopper and locust populations.

\section{Provider of biological control agents}

Like some other countries worldwide, many countries in this region have provided biocontrol agents to other countries in the region, or to other world regions. Trinidad and Tobago 
imported many species for arthropod control and distributed these imported species and native species across the Caribbean, as well as providing them to several South and Central American countries (see Chapter 29: Trinidad and Tobago). For a long time Argentina has been playing a very important role as provider of weed biocontrol agents to other world regions (see Chapter 2: Argentina), while Trinidad and Tobago have also provided several weed biocontrol agents to other countries.

\section{Governmental support and guidance for development of IPM and biocontrol}

In most countries in the region, governmental support for the development of IPM and biocontrol is limited. There are some countries in the region that are showing an active approach in sustainable pest management by strategies to reduce chemical control and replace it with IPM and biocontrol programmes. Examples are Bolivia, Cuba, Jamaica and Peru.

\section{Proactive approach with regard to control of potential invading organisms}

Often, pest control activities are planned only after a new pest has entered a country. This then usually results in attempts to eradicate the pest, which generally involves frequent chemical pesticide applications that rarely have the intended effect of eradication. Mexico has taken the initiative to compile risk scenarios for more than 1,200 potential pests, of which more than 1,000 are not yet present in the country. For some of these species, biocontrol programmes are being designed. Jamaica is following a similar approach.

\section{Impressive areas under classical biological control}

Worldwide, information about areas of pests, diseases and weeds under classical biocontrol is scattered and incomplete. The same holds for several countries treated in this book, though this information could be obtained for a number of countries and the most impressive cases, i.e. those with areas of more than 100,000 ha under biocontrol, are:

- millions of hectares of weeds in pastures, crops and nature (Argentina, Chile);
- millions of hectares with papaya mealybug and pink hibiscus mealy bug in ornamentals and various other crops and plantings (Jamaica, Mexico);

- millions of hectares of pests in cassava (Brazil);

- hundreds of thousands to millions of hectares of insect pests in pine and eucalyptus forests (Argentina, Brazil, Chile, Uruguay);

- hundreds of thousands of hectares of insect pests of citrus (Argentina, Brazil, Mexico, Peru);

- hundreds of thousands of hectares of spittlebugs in pastures (Mexico);

- hundreds of thousands to a million of hectares of wheat aphids in wheat (Brazil, Chile);

- hundreds of thousands of hectares of Rhodes grass scale in pastures (Brazil);

- hundreds of thousands of hectares of white rice borer in rice (Ecuador);

- hundreds of thousands of hectares of sugarcane borers in sugarcane (Ecuador); and

- hundreds of thousands of hectares of mealybugs in various crops (Chile).

\section{Impressive areas under augmentative biological control}

Areas under augmentative biocontrol are usually better documented than those for classical biocontrol, both for the world and for the Latin American and Caribbean region. When data for this region are compared with information presented about worldwide use of augmentative control (van Lenteren et al., 2019), the conclusion is that application is by far the largest in Latin America. The major augmentative projects, i.e. those with more than 100,000 ha under biocontrol, in the region are:

- millions of hectares of Asian citrus psyllid in citrus (Brazil);

- millions of hectares of coffee berry borer in coffee (Brazil);

- millions of hectares of lepidopterans in maize (Brazil);

- millions of hectares of soil-borne nematodes in corn (Brazil);

- millions of hectares of cotton boll worm in cotton (Brazil);

- millions of hectares of hemipterans and lepidopterans in soybean (Bolivia, Brazil, Cuba); 
- millions of hectares of soil-borne diseases in soybean (Brazil);

- millions of hectares of sugarcane borers and spittlebugs in sugarcane (Brazil, Colombia);

- hundreds of thousands of hectares of mate tree borer in mate (Brazil);

- hundreds of thousands of hectares of whitefly in soybean (Brazil);

- hundreds of thousands of hectares of soilborne nematodes in soybean (Brazil);

- hundreds of thousands of hectares of lepidopterans and coleopterans in various crops (Brazil);

- hundreds of thousands of hectares of spittlebugs in sugarcane (Bolivia, Dominican Republic);

- hundreds of thousands of hectares of potato weevils in potato (Bolivia);

- hundreds of thousands of hectares of lepidopterans in quinoa (Bolivia);

- hundreds of thousands of hectares of hemipterans and lepidopterans in various crops (Cuba);

- hundreds of thousands of hectares of rice stem stink bug in rice (Dominican Republic);

- hundreds of thousands of hectares of sugarcane aphid in sorghum (Mexico);

- hundreds of thousands of hectares of sugarcane borer in sugarcane (Mexico);

- hundreds of thousands of hectares of aphids and budworms in cotton (Peru); and

- $\quad$ hundreds of thousands of hectares of pests and diseases in sugarcane (Peru).

\subsubsection{Achievements in areas under biocontrol in Latin America and the Caribbean}

An important indicator for achievements is the area under biocontrol in a certain country. Unfortunately, even when exhaustive attempts were made to obtain those figures for each of the countries, for some countries data were simply not available and for several others data were incomplete. It was particularly difficult to obtain data for conservation and natural biocontrol. Although papers quite often mentioned that classical biocontrol programmes successfully developed in the period 1880-1969 were still functioning well, specification of the areas on which these programmes still worked was lacking. In such cases attempts were made to estimate the areas under biocontrol by using information about areas harvested in 2016 or 2017 published by FAO (http://www.fao.org/ faostat/en/\#data/qc). Data for augmentative programmes were easier to obtain, but for conservation and natural biocontrol authors often only mentioned that these types of control occurred (eight countries for conservation biocontrol and 12 for natural control) and did not specify on how many hectares. Areas under biocontrol are summarized in Table 32.3. The data indicate that classical biocontrol is applied on $30,747,889$ ha, augmentative biocontrol on $31,381,131$ ha, conservation biocontrol on 447,114 ha and natural control on 2,001,846 ha. As already said above, the figure for natural control will be vastly underestimated, as this form of control was not considered or studied by many countries. However, it is interesting to see that prospecting for natural enemies and determining their role in natural control is now on the research agenda of several countries (see Table 32.2).

When calculating total areas under biocontrol, attempts were made to minimize overestimates by checking whether pests in a certain crop were under more than one type of biocontrol. In these cases, the largest area under biocontrol for a certain type of biocontrol was taken as the estimate. For example, under the heading 'classical biocontrol' in Table 32.3, data are included for fortuitous biocontrol but these are not included in the estimate of $30,747,889$ ha for classical biocontrol. In cases where more species of natural enemies are used for classical biocontrol of different pest species, only the estimate for the biocontrol agent applied on the largest area is used in the estimate for that crop. However, for augmentative biocontrol, the estimate of the total area treated given above $(31,381,131$ ha) is corrected for cases where more than one type of augmentative biocontrol is used to control more than one pest, but not for overlap with classical biocontrol. When correcting this figure for overlap with classical biocontrol. i.e. cases where classical biocontrol is active in controlling a certain pest in the total area of a certain crop and where augmentative biocontrol is applied for control of other pests in that crop, the area only under 
Table 32.3. Types of biocontrol and surface areas (ha) currently treated in Latin America and the Caribbean.

\begin{tabular}{|c|c|c|c|c|c|c|c|}
\hline Country & $\begin{array}{l}\text { Classical biocontrol } \\
(\mathrm{CBC})+(\text { Fortuitous } \\
\text { biocontrol }(\mathrm{FBC}))\end{array}$ & $\begin{array}{l}\text { Augmentative biocontrol } \\
\text { (ABC) }\end{array}$ & $\begin{array}{l}\text { Conservation } \\
\text { biocontrol } \\
\text { (ConsBC) }\end{array}$ & $\begin{array}{c}\text { Natural } \\
\text { control (NC) }\end{array}$ & $\begin{array}{l}\text { Country } \\
\text { surface (ha) }\end{array}$ & Inhabitants ${ }^{b}$ & $\begin{array}{c}\text { Biocontrol (ha): } \\
\text { per ha land / } \\
\text { per inhabitant }\end{array}$ \\
\hline Argentina & $4,298,000$ & 26,778 & & & $278,040,000$ & $44,000,000$ & $0.015 / 0.098$ \\
\hline Barbados & 3,069 & 300 & & & 43,000 & 290,000 & 0.078 / 0.012 \\
\hline Belize & 16,000 & & & & $2,297,000$ & 360,000 & $0.007 / 0.044$ \\
\hline Bolivia & 54,000 & $\begin{array}{l}412,000(+1,112,800 \\
\text { overlap with } \mathrm{NC})\end{array}$ & & $1,558,000$ & $109,858,000$ & $11,000,000$ & $0.018 / 0.184$ \\
\hline Brazil & $3,012,000$ & $\begin{array}{c}21,762,000(+3,711,000 \\
\text { overlap within } A B C)\end{array}$ & & & $851,577,000$ & $207,360,000$ & $0.029 / 0.119$ \\
\hline Chile & $7,726,465$ & 62,197 & & & $75,670,000$ & $17,800,000$ & $0.103 / 0.438$ \\
\hline Colombia & $\begin{array}{l}\text { 4,000 (+ 4,000 overlap } \\
\text { with FBC) }\end{array}$ & 378,896 & $+(?)$ & $+(?)$ & $114,174,900$ & $47,700,000$ & $0.003 / 0.008$ \\
\hline Costa Rica & $+(?)$ & 15,650 & $+(?)$ & $+(?)$ & $5,110,000$ & $4,930,000$ & $0.003 / 0.003$ \\
\hline Cuba & 723,000 & $2,221,306$ & 140,000 & 140,000 & $10,988,000$ & $11,150,000$ & $0.293 / 0.224$ \\
\hline Dominica & 2,750 & & & $+(?)$ & 75,000 & 73,900 & $0.037 / 0.037$ \\
\hline Dominican Rep. & $\begin{array}{l}169,691(+67,704 \text { overlap } \\
\text { with FBC) }\end{array}$ & $\begin{array}{l}290,451(+66,000 \\
\text { overlap with } \mathrm{CBC})\end{array}$ & & $+(?)$ & $4,867,000$ & $10,735,000$ & $0.095 / 0.043$ \\
\hline Ecuador & 558,853 & 66,293 & 150,000 & $+(?)$ & $25,637,000$ & $16,300,000$ & $0.030 / 0.048$ \\
\hline El Salvador & $\begin{array}{l}1,500(+1,500 \text { overlap } \\
\text { with FBC) }\end{array}$ & $+(?)$ & & 755 & $2,104,000$ & $6,000,000$ & $0.001 / 0.000$ \\
\hline French Guiana & 20,903 & $+(?)$ & $+(?)$ & & $9,280,700$ & $1,125,160$ & $0.002 / 0.019$ \\
\hline Guatemala & 1,500 & 19,976 & & 275,000 & $10,889,000$ & $15,500,000$ & 0.027 / 0.019 \\
\hline Guyana & 44,000 & 12,000 & 150,000 & & $21,497,000$ & 740,000 & $0.010 / 0.278$ \\
\hline Haiti & 56,967 & & & $+(?)$ & $2,775,000$ & $10,900,000$ & $0.021 / 0.005$ \\
\hline Honduras & 1 & 25,400 & $+(?)$ & $+(?)$ & $11,249,000$ & $9,000,000$ & $0.002 / 0.003$ \\
\hline Jamaica & $\begin{array}{c}1,059,676(+1,023,923 \\
\text { overlap with FBC) }\end{array}$ & 7,846 & & 23,923 & $1,099,000$ & $2,700,000$ & $0.971 / 0.404$ \\
\hline Mexico & $11,810,404$ & 763,000 & & $+(?)$ & $196,437,500$ & $124,100,000$ & $0.064 / 0.101$ \\
\hline Nicaragua & $+(?)$ & 10,484 & & & $13,037,000$ & $6,000,000$ & $0.001 / 0.002$ \\
\hline Panama & 19 & 38,630 & 177 & 3,416 & $7,542,000$ & $3,750,000$ & $0.006 / 0.011$ \\
\hline Paraguay & & $+(?)$ & $+(?)$ & & $40,675,200$ & $7,000,000$ & $? / ?$ \\
\hline Peru & 108,507 & 330,327 & $+(?)$ & $+(?)$ & $128,522,000$ & $31,000,000$ & $0.003 / 0.014$ \\
\hline
\end{tabular}


Table 32.3. Continued.

\begin{tabular}{|c|c|c|c|c|c|c|c|}
\hline Country & $\begin{array}{l}\text { Classical biocontrol } \\
(\mathrm{CBC})+(\text { Fortuitous } \\
\text { biocontrol (FBC) })\end{array}$ & $\begin{array}{l}\text { Augmentative biocontrol } \\
(\mathrm{ABC})\end{array}$ & $\begin{array}{l}\text { Conservation } \\
\text { biocontrol } \\
(\text { ConsBC) }\end{array}$ & $\begin{array}{c}\text { Natural } \\
\text { control (NC) }\end{array}$ & $\begin{array}{l}\text { Country } \\
\text { surface (ha) }\end{array}$ & Inhabitants ${ }^{b}$ & $\begin{array}{l}\text { Biocontrol (ha): } \\
\text { per ha land / } \\
\text { per inhabitant }\end{array}$ \\
\hline Puerto Rico & $\begin{array}{l}10,529(+1,896 \text { overlap } \\
\text { with FBC) }\end{array}$ & $+(?)$ & 6,937 & $+(?)$ & 887,000 & $3,350,000$ & $0.020 / 0.005$ \\
\hline $\begin{array}{l}\text { Remaining } \\
\text { Caribs. }\end{array}$ & $+(?)$ & $+(?)$ & $+(?)$ & $+(?)$ & $1,744,200$ & $1,200,000$ & $? / ?$ \\
\hline Suriname & $+(?)$ & 0.5 & & 752 & $16,382,000$ & 600,000 & $0.000 / 0.001$ \\
\hline $\begin{array}{l}\text { Trinidad and } \\
\text { Tobago }\end{array}$ & 32,390 & 350 & $+(?)$ & $+(?)$ & 513,000 & $1,200,000$ & 0.064 / 0.010 \\
\hline Uruguay & $1,016,165$ & 1,356 & & & $17,622,000$ & $3,360,000$ & $0.058 / 0.303$ \\
\hline Venezuela & 17,500 & 46,000 & & & $91,205,000$ & $31,300,000$ & $0.001 / 0.002$ \\
\hline Total & $\begin{array}{l}30,747,889(31,846,912 \\
\quad \text { with FBC) }\end{array}$ & $\begin{array}{l}\mathbf{3 1 , 3 8 1 , 1 3 1}(26,491,331 \\
\text { without overlap with } \\
\text { CBC) }\end{array}$ & 447,114 & $2,001,846$ & & & \\
\hline
\end{tabular}

aCountry surface areas for 2017 or 2018 based on World Bank data (https://data.worldbank.org/indicator/ag.srf.totl.k2)

bInhabitants mainly based on data from Central Intelligence Agency (CIA) (https://www.cia.gov/library/publications/the-world-factbook/geos/) 
augmentative biocontrol is $26,491,331$ ha. Areas treated with products based on B. thuringiensis are not included in the estimates, because these products do not contain a living organism and thus are not considered to be biocontrol agents.

More data for each country (crop, pest, type of biocontrol used and areas under biocontrol for each type of biocontrol) are provided as supplementary material. Also, a list of all organisms (biocontrol agents, pests, crops, weeds, etc.) with author name, order, family and common name of the organism, and the country chapters in which these organisms are mentioned is provided as supplementary material. A preliminary check of the list with all organisms mentioned in the book indicates that 715 species of parasitoids, 436 species of predatory arthropods and 204 pathogens are mentioned in relation to biocontrol projects in Latin America and the Caribbean. This list with names of all organisms can be used, for example, to check where certain natural enemies and microbial agents have been found and whether they have been successfully applied in biocontrol programmes. Providing current locations of biocontrol agents as done in this list may help in simplifying issues related to Access and Benefit Sharing regulations (see Section 32.4.1 on factors limiting development and implementation of biocontrol, below).

Six countries (Argentina, Brazil, Chile, Jamaica, Mexico and Uruguay) apply classical biocontrol on more than 1 million hectares, while four countries (Cuba, Dominican Republic, Ecuador, Peru) use classical biocontrol on more than 100,000 ha (Table 32.3). Two countries (Brazil and Cuba) apply augmentative biocontrol on more than 1 million hectares, while five countries (Bolivia, Colombia, Dominican Republic, Mexico, Peru) use augmentative biocontrol on more than 100,000 ha. Three countries (Cuba, Ecuador and Guyana) use conservation biocontrol on more than 100,000 ha, while natural control is documented for more than 1 million hectares in Bolivia and more than 100,000 ha in two countries: Cuba and Guatemala.

Although it was said earlier that a country's area under biocontrol is an important indicator for the country's achievements, this statement needs some qualification. Surface areas differ considerably among the countries in Latin America and the Caribbean. For example, Barbados consists of only 43,000 ha, while Brazil covers 851,577,000 ha (Table 32.3). When using total surface areas for each country, use of biocontrol per hectare of the total surface ranks highest and above 0.1 ha per hectare for Chile, Cuba, Jamaica and Barbados, whereas the Dominican Republic, Mexico, Trinidad and Tobago and Uruguay have more than 0.05 ha per hectare under biocontrol. However, total country surfaces do not provide the best figures for a comparison of achievements, as some countries have vast areas where agriculture is not practised or even possible. Thus, many corrections should be made to these total country surface values for better comparisons. Another way to rank country achievements in biocontrol is to calculate the area under biocontrol per inhabitant. This results in nine countries (Argentina, Bolivia, Brazil, Chile, Cuba, Guyana, Jamaica, Mexico, Trinidad and Tobago) with at least 0.1 ha of biocontrol per inhabitant (Table 32.3). Each way of ranking has its advantages and disadvantages, but the most important conclusion that can be drawn from the data in Table 32.3 is that Latin America and the Caribbean are currently world leaders in biocontrol.

\subsection{BIOCAT Data on Classical Biological Control in Latin America and the Caribbean}

Summary tables and lists for classical biocontrol introductions for the region were compiled for the use of insects as classical biocontrol agents against insect pests. The numbers were generated from the BIOCAT database (Cock et al., 2016), based on the corrected version used by Cock (2019), which can be referred to as BIOCAT 2010.3. Each combination of biocontrol agent, primary target, release country and date or period of release was treated as one introduction. Introductions that were reported to have achieved at least partial control were classed as 'successful'. It should be noted that BIOCAT 2010.3 is not up to date and the numbers should not be relied upon for the past decade or two. Nevertheless, the numbers capture the 
great majority of insect classical biocontrol introductions and provide valid comparisons between countries, regions, numbers of targets and biocontrol agents, establishments and successes.

Table 32.4 summarizes the records for control of insect pests by insect natural enemies in the region in classical biocontrol. The country chapters in this book mention classical biocontrol projects, but in a qualitative way. The table illustrates that many introductions have been made and that $30 \%$ of the introductions resulted in establishment, which is an impressively high rate. Also the high percentage of target pest species controlled (34\%) and the percentage of successful agent species (15\%) support the conclusion that classical biocontrol has been a profitable pest management method in this region and that many countries made use of it.

In Table 32.5, the introduced species of natural enemies that contributed to classical biocontrol in the region are listed. Most of these species are, not surprisingly, also mentioned in the country-specific chapters. Exceptions are three species that, according to the BIOCAT database (based on Zúñiga, 1985), were introduced

Table 32.4. Summary of records included in BIOCAT2010.3 concerning classical biological control of insects by insect biocontrol agents in Latin America and the Caribbean.

\begin{tabular}{lr}
\hline Category & Number \\
\hline $\begin{array}{l}\text { No. of introductions (total records) } \\
\text { No. of establishments (excluding }\end{array}$ & 964 \\
$\quad$ temporary) & 287 \\
No. of primary pest targets & 118 \\
No. of agent species & 387 \\
No. of countries & 36 \\
No. of successful biological control agent & 128 \\
$\quad$ introductions & \\
No. of successful biological control agent & 57 \\
$\quad$ species & 103 \\
No. of successful programmes & 40 \\
No. of different pest species controlled & 29 \\
No. of countries reporting at least one & \\
$\quad$ success & \\
\hline
\end{tabular}

aEach agent/target country/year is a separate introduction/ establishment, e.g. an introduction of the same biocontrol agent from six countries at the same time counts as one introduction, but two introductions of the same biocontrol agent 10 years apart count as two introductions. into Chile more than 50 years ago and contributed to success in forestry pest biocontrol, but are not mentioned in the Chilean chapter: Habrolepis dalmanni (Westwood) for complete control of Asterodiaspis quercicola (Bouché) in 1928; Leucopis obscura Haliday for partial control of Pineus boerneri Annand in 1945; and Rhaphitelus maculatus Walker for partial control of Scolytus rugulosus Müller in 1915-1916. The number of insect natural enemy species used in classical biocontrol (57) is much lower than the total number of arthropod natural enemy species mentioned in the country chapters (1150). This large difference is to be expected and can be explained as follows. The list for the country chapters: (i) includes all arthropod natural enemies mentioned, both the effective and ineffective agents, while Table 32.5 only includes successful species; (ii) includes many predatory mites, whereas Table 32.5 does not; and (iii) includes species used in all types of biocontrol, where Table 32.5 is limited to classical biocontrol. Particularly this last reason explains a large part of the difference, because in augmentative biocontrol many different species of natural enemies have been tried and are used in different countries (see, for example, Chapter 6: Brazil and Chapter 25: Peru). In classical biocontrol it is common to use the same natural enemies in different countries against the same pest (see the supplementary table with numbers of introductions of insect biocontrol agents per 10-year period for each country in Latin America and the Caribbean). Many more parasitoids have been successfully used than predators.

In Table 32.6 the names of the pest species are presented that were controlled as a result of the introduction of natural enemy species mentioned in Table 32.5.

A list of countries that have reported at least one insect pest successfully control by classical biocontrol and a table with numbers of introductions of insect biocontrol agents each decade for each country in Latin America and the Caribbean are presented as supplementary material.

Ten species of entomopathogens have been released in Latin America and the Caribbean for use in classical biocontrol (Table 32.7 and Hajek et al., 2016). Seven of the entomopathogens became established in at least one country and ten 
Table 32.5. List of species of insect natural enemies that have contributed to a classical biological control success somewhere in Latin America and the Caribbean (retrieved from BIOCAT 2010.3).

\begin{tabular}{|c|c|c|c|c|}
\hline Biological control agent & Guild & Family & Primary target & $\begin{array}{c}\text { No. of countries } \\
\text { with success }\end{array}$ \\
\hline Aceratoneuromyia indica & Parasitoid & Eulophidae & Anastrepha ludens & 1 \\
\hline Adalia bipunctata & Predator & Coccinellidae & Aphids & 1 \\
\hline Aganaspis pelleranoi & Parasitoid & Figitidae & Anastrepha striata & 1 \\
\hline Amitus hesperidum & Parasitoid & Platygastridae & $\begin{array}{l}\text { Aleurocanthus } \\
\text { woglumi }\end{array}$ & 2 \\
\hline Amitus spiniferus & Parasitoid & Platygastridae & $\begin{array}{l}\text { Aleurothrixus } \\
\text { floccosus }\end{array}$ & 1 \\
\hline Anagyrus kamali & Parasitoid & Encyrtidae & $\begin{array}{l}\text { Maconellicoccus } \\
\text { hirsutus }\end{array}$ & 11 \\
\hline Anagyrus saccharicola & Parasitoid & Encyrtidae & $\begin{array}{l}\text { Saccharicoccus } \\
\text { sacchari }\end{array}$ & 1 \\
\hline Aphelinus mali & Parasitoid & Aphelinidae & Eriosoma lanigerum & 8 \\
\hline Aphidius matricariae & Parasitoid & Braconidae & Aphids & 1 \\
\hline Aphidius smithi & Parasitoid & Braconidae & Acyrthosiphon pisum & 2 \\
\hline Aphytis holoxanthus & Parasitoid & Aphelinidae & $\begin{array}{l}\text { Chrysomphalus } \\
\text { aonidum }\end{array}$ & 4 \\
\hline Aphytis lepidosaphes & Parasitoid & Aphelinidae & Lepidosaphes beckii & 6 \\
\hline Aphytis melinus & Parasitoid & Aphelinidae & Aonidiella aurantii & 1 \\
\hline Aphytis roseni & Parasitoid & Aphelinidae & $\begin{array}{l}\text { Selenaspidus } \\
\text { articulatus }\end{array}$ & 1 \\
\hline Aphytis sp. & Parasitoid & Aphelinidae & $\begin{array}{l}\text { Lepidosaphes gloverii } \\
\text { and Aonidiella } \\
\text { aurantii }\end{array}$ & 2 \\
\hline Billaea claripalpis & Parasitoid & Tachinidae & Diatraea saccharalis & 2 \\
\hline Cales noacki & Parasitoid & Aphelinidae & $\begin{array}{l}\text { Aleurothrixus } \\
\text { floccosus }\end{array}$ & 1 \\
\hline Chilocorus cacti & Predator & Coccinellidae & $\begin{array}{c}\text { Bambusaspis } \\
\text { bambusae }\end{array}$ & 1 \\
\hline Cladis nitidula & Predator & Coccinellidae & $\begin{array}{c}\text { Bambusaspis } \\
\text { bambusae }\end{array}$ & 1 \\
\hline Coccophagus gurneyi & Parasitoid & Aphelinidae & $\begin{array}{c}\text { Pseudococcus } \\
\text { calceolariae }\end{array}$ & 1 \\
\hline Comperiella bifasciata & Parasitoid & Encyrtidae & Aonidiella aurantii & 1 \\
\hline Copidosoma floridanum & Parasitoid & Encyrtidae & Trichoplusia ni & 1 \\
\hline Cotesia flavipes & Parasitoid & Braconidae & Diatraea saccharalis & 3 \\
\hline Cotesia glomerata & Parasitoid & Braconidae & Pieris brassicae & 1 \\
\hline Cotesia sesamiae & Parasitoid & Braconidae & Diatraea saccharalis & 1 \\
\hline Cotesia vestalis & Parasitoid & Braconidae & Plutella xylostella & 1 \\
\hline Cryptognatha nodiceps & Predator & Coccinellidae & Aspidiotus destructor & 1 \\
\hline Cryptolaemus montrouzieri & Predator & Coccinellidae & $\begin{array}{l}\text { Maconellicoccus } \\
\text { hirsutus }\end{array}$ & 11 \\
\hline Encarsia berlesei & Parasitoid & Aphelinidae & $\begin{array}{l}\text { Pseudaulacaspis } \\
\text { pentagona }\end{array}$ & 4 \\
\hline Encarsia clypealis & Parasitoid & Aphelinidae & $\begin{array}{l}\text { Aleurocanthus } \\
\text { woglumi }\end{array}$ & 1 \\
\hline Encarsia noyesi & Parasitoid & Aphelinidae & Aleurodicus cocois & 1 \\
\hline Encarsia opulenta & Parasitoid & Aphelinidae & $\begin{array}{l}\text { Aleurocanthus } \\
\text { woglumi }\end{array}$ & 5 \\
\hline Encarsia smithi & Parasitoid & Aphelinidae & $\begin{array}{l}\text { Aleurocanthus } \\
\text { woglumi }\end{array}$ & 1 \\
\hline Encarsia sp. & Parasitoid & Aphelinidae & Lepidosaphes beckii & $\begin{array}{c}1 \\
\text { Continued }\end{array}$ \\
\hline
\end{tabular}


Table 32.5. Continued.

\begin{tabular}{|c|c|c|c|c|}
\hline Biological control agent & Guild & Family & Primary target & $\begin{array}{c}\text { No. of countries } \\
\text { with success }\end{array}$ \\
\hline Eretmocerus serius & Parasitoid & Aphelinidae & $\begin{array}{c}\text { Aleurocanthus } \\
\text { woglumi }\end{array}$ & 6 \\
\hline Gyranusoidea indica & Parasitoid & Encyrtidae & $\begin{array}{l}\text { Maconellicoccus } \\
\quad \text { hirsutus }\end{array}$ & 1 \\
\hline Habrolepis dalmanni ${ }^{\mathrm{a}}$ & Parasitoid & Encyrtidae & $\begin{array}{c}\text { Asterodiaspis } \\
\text { quercicola }\end{array}$ & 1 \\
\hline Hippodamia convergens & Predator & Coccinellidae & Schizaphis graminum & 1 \\
\hline Leucopis obscura ${ }^{a}$ & Predator & Chamaemyiidae & Pineus boerneri & 1 \\
\hline Lixophaga diatraeae & Parasitoid & Tachinidae & Diatraea saccharalis & 4 \\
\hline Lysiphlebus testaceipes & Parasitoid & Braconidae & Schizaphis graminum & 1 \\
\hline Lydella minense & Parasitoid & Tachinidae & Diatraea saccharalis & 4 \\
\hline Metaphycus anneckei & Parasitoid & Encyrtidae & Saissetia oleae & 1 \\
\hline Metaphycus helvolus & Parasitoid & Encyrtidae & Saissetia spp. & 2 \\
\hline Neodusmetia sangwani & Parasitoid & Encyrtidae & Antonina graminis & 1 \\
\hline Psyllaephagus pilosus & Parasitoid & Encyrtidae & Ctenarytaina eucalypti & 1 \\
\hline Pteroptrix smithi & Parasitoid & Aphelinidae & $\begin{array}{l}\text { Chrysomphalus } \\
\text { aonidum }\end{array}$ & 1 \\
\hline Rhaphitelus maculatus ${ }^{a}$ & Parasitoid & Pteromalidae & Scolytus rugulosus & 1 \\
\hline Rodolia cardinalis & Predator & Coccinellidae & Icerya purchasi & 11 \\
\hline Telenomus alsophilae & Parasitoid & Platygastridae & Oxydia trychiata & 1 \\
\hline Telenomus remus & Parasitoid & Platygastridae & $\begin{array}{l}\text { Spodoptera } \\
\text { frugiperda }\end{array}$ & 2 \\
\hline Telenomus rowani & Parasitoid & Platygastridae & Rupella albinella & 1 \\
\hline Trichogramma minutum & Parasitoid & Trichogrammatidae & Diatraea saccharalis & 1 \\
\hline Trichogramma pretiosum & Parasitoid & Trichogrammatidae & Diatraea saccharalis & 1 \\
\hline $\begin{array}{l}\text { Trichogramma } \\
\text { semifumatum }\end{array}$ & Parasitoid & Trichogrammatidae & Diatraea saccharalis & 1 \\
\hline Trichogramma sp. & Parasitoid & Trichogrammatidae & Diatraea saccharalis & 1 \\
\hline Tytthus mundulus & Predator & Miridae & $\begin{array}{l}\text { Perkinsiella } \\
\quad \text { saccharicida }\end{array}$ & 1 \\
\hline
\end{tabular}

aSpecies not mentioned in Chilean chapter.

target pest species were brought under classical biocontrol. Correspondence between species of entomopathogens mentioned in the countryspecific chapters and Table 32.7 is poor and six of the ten entomopathogens are not mentioned in the country-specific chapters: Hirsutella thompsonii (Argentina), Neozygites parvispora (Barbados), Metarhizium anisopliae (Guyana), Aschersonia aleyrodis (Virgin Islands), Romanomermis culicivorax (Colombia and Puerto Rico), Romanomermis iyengari (Cuba) and Trichoplusia ni nucleopolyhedrovirus (TnNPV) (Colombia). The difference for the first four species may be explained by the fact that they did not control the pest and are therefore not mentioned in the respective country-specific chapters. The two species of the genus Romanomermis might not have been mentioned in the country-specific chapters for Cuba and Puerto Rico because they concern agents controlling mosquitoes vectoring human diseases, a topic that may have escaped the attention of the authors.

The number of releases of insect natural enemies per decade is given in Fig. 32.1 and shows an increase during the initial four decades, which is interrupted as a result of the Second World War, but the increase continues in the 1950s, peaks during the 1970s and then dramatically drops. The peak in the 1960s and 1970 s reflects a period when classical biocontrol agents were easily transported by air and introduced rather indiscriminately without careful pre-release studies, combined with the import and release of known biocontrol agents 
Table 32.6. Pest target species reported to have been successfully controlled by classical biological control somewhere in Latin America and the Caribbean (retrieved from BIOCAT 2010.3)

\begin{tabular}{|c|c|c|c|c|}
\hline Target pest & Family & Crop & $\begin{array}{l}\text { No. of biocontrol agents } \\
\text { involved in success }\end{array}$ & $\begin{array}{l}\text { No. of territories } \\
\text { reporting success }\end{array}$ \\
\hline Acyrthosiphon pisum & Aphididae & Peas, lucerne & 1 & 2 \\
\hline Aleurocanthus woglumi & Aleyrodidae & Citrus & 4 & 9 \\
\hline Aleurodicus cocois & Aleyrodidae & Coconut, palms & 1 & 1 \\
\hline Aleurothrixus floccosus & Aleyrodidae & Citrus & 2 & 2 \\
\hline Anastrepha ludens & Tephritidae & Fruit & 1 & 1 \\
\hline Anastrepha striata & Tephritidae & Citrus & 1 & 1 \\
\hline Antonina graminis & Pseudococcidae & Pasture grasses & 1 & 1 \\
\hline Aonidiella aurantii & Diaspididae & Citrus & 3 & 2 \\
\hline Aspidiotus destructor & Diaspididae & Coconut & 1 & 1 \\
\hline Asterodiaspis quercicola & Asterolecaniidae & Oak & 1 & 1 \\
\hline Bambusaspis bambusae & Asterolecaniidae & Bamboo & 2 & 1 \\
\hline Chrysomphalus aonidum & Diaspididae & Citrus & 2 & 4 \\
\hline Ctenarytaina eucalypti & Psyllidae & Eucalyptus & 1 & 1 \\
\hline Diatraea rosa & Crambidae & Sugarcane & 1 & 1 \\
\hline Diatraea saccharalis & Crambidae & Sugarcane, maize & 8 & 10 \\
\hline Eriosoma lanigerum & Aphididae & Apple & 1 & 8 \\
\hline Icerya montserratensis & Monophlebidae & Citrus & 1 & 1 \\
\hline Icerya purchasi & Monophlebidae & Citrus, etc. & 1 & 11 \\
\hline Lepidosaphes beckii & Diaspididae & Citrus & 2 & 7 \\
\hline Lepidosaphes gloverii & Diaspididae & Citrus & 1 & 1 \\
\hline Maconellicoccus hirsutus & Pseudococcidae & Various trees and ornamentals & 3 & 11 \\
\hline Nipaecoccus nipae & Pseudococcidae & Various trees & 1 & 1 \\
\hline Oxydia trychiata & Geometridae & Cypress & 1 & 1 \\
\hline Perkinsiella saccharicida & Cicadellidae & Sugarcane & 1 & 1 \\
\hline Pieris brassicae & Pieridae & Brassicas & 1 & 1 \\
\hline Pineus boerneri & Cicadellidae & Pinus radiata & 1 & 1 \\
\hline Planococcus citri & Pseudococcidae & Fruit trees, ornamentals & 1 & 1 \\
\hline Plutella xylostella & Plutellidae & Brassicas & 1 & 1 \\
\hline Pseudaulacaspis pentagona & Diaspididae & Mulberry, peach & 1 & 4 \\
\hline Pseudococcus calceolariae & Pseudococcidae & $?$ & 1 & 1 \\
\hline Rupella albinella & Crambidae & Rice & 1 & 1 \\
\hline
\end{tabular}


Table 32.6. Continued.

\begin{tabular}{|c|c|c|c|c|}
\hline Target pest & Family & Crop & $\begin{array}{l}\text { No. of biocontrol agents } \\
\text { involved in success }\end{array}$ & $\begin{array}{l}\text { No. of territories } \\
\text { reporting success }\end{array}$ \\
\hline Saccharicoccus sacchari & Pseudococcidae & Sugarcane & 1 & 1 \\
\hline Saissetia coffeae & Coccidae & Citrus & 1 & 1 \\
\hline Saissetia oleae & Coccidae & Citrus & 2 & 2 \\
\hline Schizaphis graminum & Aphididae & Wheat, cereals & 2 & 2 \\
\hline Scolytus rugulosus & Curculionidae & Peach & 1 & 1 \\
\hline Selenaspidus articulatus & Diaspidae & Citrus & 1 & 1 \\
\hline Spodoptera frugiperda & Noctuidae & Various arable & 1 & 1 \\
\hline Spodoptera spp. & Noctuidae & Various arable & 1 & 1 \\
\hline Trichoplusia ni & Noctuidae & Various arable & 1 & 1 \\
\hline 'Aphids' & Aphididae & $?$ & 2 & 1 \\
\hline
\end{tabular}


Table 32.7. Summary of records concerning use of entomopathogens in classical biological control in Latin America and the Caribbean (retrieved from Hajek et al., 2016).

\begin{tabular}{|c|c|c|c|c|c|}
\hline Country & Releases & Biocontrol agent & Established & Target species & $\begin{array}{l}\text { Targets } \\
\text { controlled }\end{array}$ \\
\hline $\begin{array}{l}\text { Bacteria } \\
\text { Fungi }\end{array}$ & 0 & 0 & 0 & 0 & 0 \\
\hline Argentina & 3 & $\begin{array}{l}\text { Fusarium coccophilum } \\
\text { Hirsutella thompsonii }\end{array}$ & 1 & $\begin{array}{l}\text { Aonidiella aurantia } \\
\text { Eriophyes sheldoni and } \\
\text { Phyllocoptruta oleivora }\end{array}$ & 1 \\
\hline Barbados & 1 & Neozygites parvispora & 0 & Thrips tabaci & 0 \\
\hline Guyana & 1 & Metarhizium anisopliae & 1 & Aeneolamia flavilatera & 0 \\
\hline $\begin{array}{l}\text { US Virgin } \\
\text { Islands }\end{array}$ & 1 & Aschersonia aleyrodis & 0 & $\begin{array}{l}\text { Aleurodicus cocois \& } \\
\text { Aleurothrixus } \\
\text { floccosus }\end{array}$ & 0 \\
\hline \multicolumn{6}{|l|}{ Microsporidia } \\
\hline Argentina & 1 & Paranosema locustae & 1 & $\begin{array}{l}\text { Dichroplus } \\
\text { maculipennis, } \\
\text { D. elongatus, } \\
\text { D. pratensis and } \\
\text { Scotussa lemniscata }\end{array}$ & 1 \\
\hline \multicolumn{6}{|l|}{ Nematodes } \\
\hline Argentina & 2 & Deladenus siricidicola & 1 & Sirex noctilio & 1 \\
\hline Brazil & 2 & Deladenus siricidicola & 1 & Sirex noctilio & 1 \\
\hline Chile & 1 & Deladenus siricidicola & 1 & Sirex noctilio & 1 \\
\hline Colombia & 1 & $\begin{array}{l}\text { Romanomermis } \\
\text { culicivorax }\end{array}$ & 1 & $\begin{array}{l}\text { Anopheles } \\
\text { nyssorhynchus } \\
\text { albimanus }\end{array}$ & 1 \\
\hline Cuba & 1 & $\begin{array}{l}\text { Romanomermis } \\
\text { iyengari }\end{array}$ & 1 & $\begin{array}{l}\text { Anopheline spp. and } \\
\text { Culicine spp. }\end{array}$ & 4 \\
\hline El Salvador & 1 & $\begin{array}{l}\text { Romanomermis } \\
\text { culicivorax }\end{array}$ & 0 & $\begin{array}{l}\text { Anopheles } \\
\text { nyssorhynchus } \\
\text { albimanus and } \\
\text { A. punctipennis }\end{array}$ & 0 \\
\hline Puerto Rico & 1 & $\begin{array}{l}\text { Romanomermis } \\
\text { culicivorax }\end{array}$ & 1 & $\begin{array}{l}\text { Scapteriscus didactylus } \\
\text { and S. abbreviatus }\end{array}$ & 1 \\
\hline Uruguay & 1 & Deladenus siricidicola & 1 & Sirex noctilio & 1 \\
\hline \multicolumn{6}{|l|}{ Viruses } \\
\hline Colombia & 1 & $\begin{array}{l}\text { Trichoplusia ni } \\
\text { nucleopolyhedrovirus } \\
\text { (TnNPV) }\end{array}$ & 1 & Trichoplusia ni & 1 \\
\hline
\end{tabular}

used successfully in other parts of the world. Interest dropped off in the 1980s when all the obvious biocontrol agents had been introduced and few major new targets for classical biocontrol were spreading in the region. Figure 32.2 presents the number of classical biocontrol successes with insect natural enemies per decade and shows a similar trend as Fig. 32.1, but with the difference of an extra peak during the 1990s, reflecting the 11 successful programmes against Maconellicoccus hibiscus around the Caribbean.

\subsection{Factors Limiting and Stimulating Biological Control in Latin America and the Caribbean}

\subsubsection{Factors limiting development and implementation of biological control}

Authors of the country chapters mention many causes that may frustrate development and implementation of biocontrol. Factors limiting biocontrol are partly summarized in Table 32.2. 


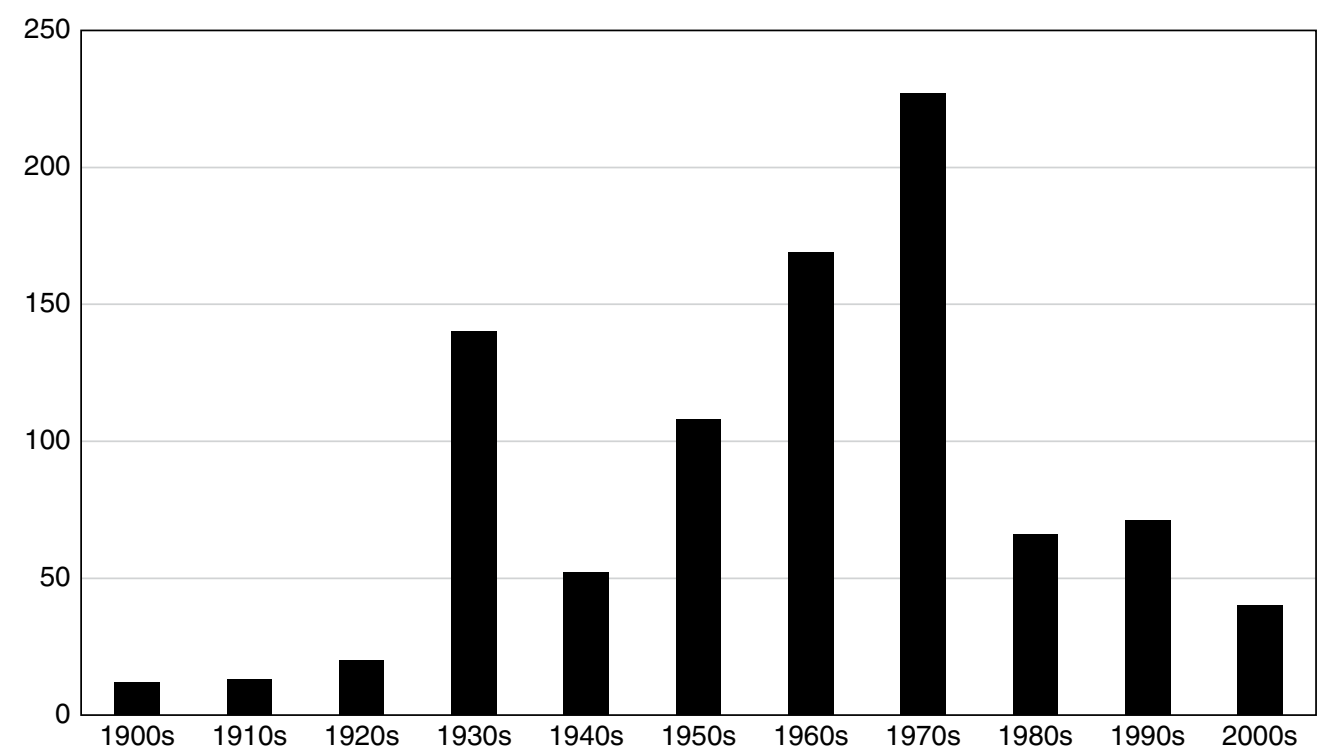

Fig. 32.1. Number of releases per decade of insect biocontrol agents for classical biological control of insect pests in Latin America and the Caribbean (retrieved from BIOCAT 2010.3).

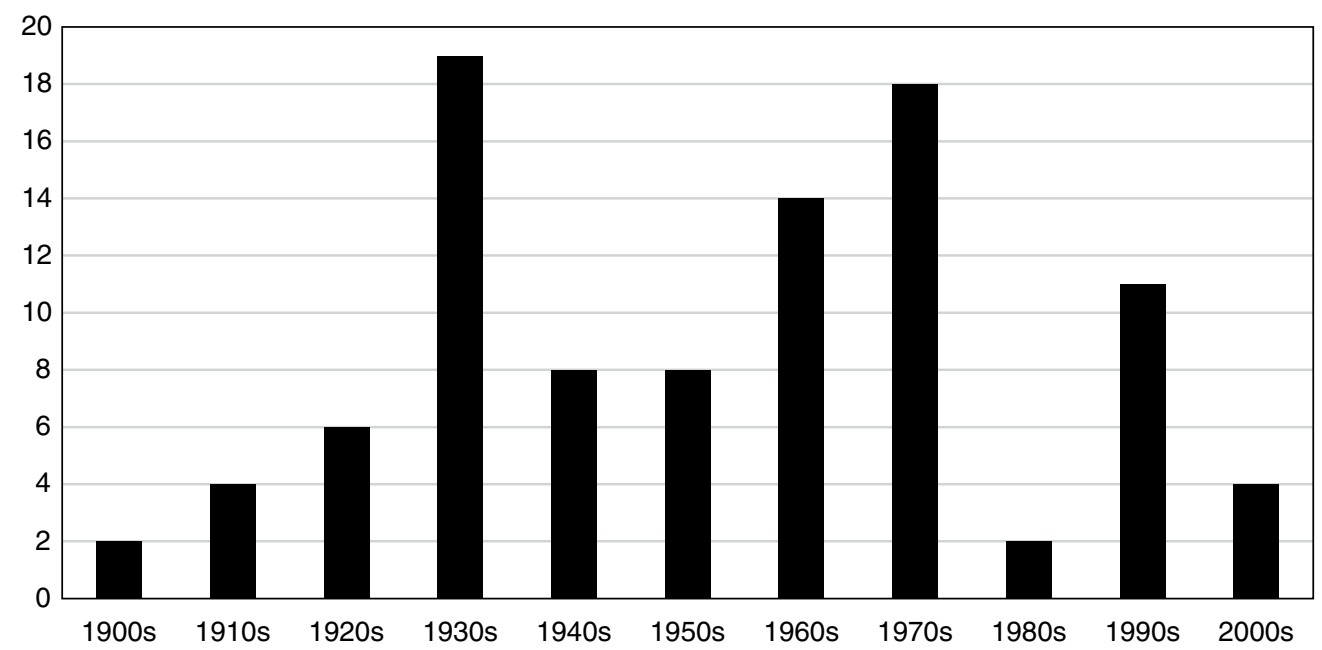

Fig. 32.2. Number of classical biological control successes of insect pests by insect biocontrol agents per decade in Latin America and the Caribbean (retrieved from BIOCAT 2010.3) Each target successfully controlled counts once for each country and is allocated to the decade when the first biocontrol agent contributing to that success was released.

The factor most often mentioned is the dominating role that the pesticide industry and their sales persons play. Pesticide companies strongly lobby at governmental levels for faster pesticide registration procedures and continuously stress the need to apply pesticides in order to be able to feed a growing human population.
Crop protection advisors prefer to advise (over-) use of pesticides, as they are sold per unit of volume and their income is based on volumes sold. Another reason why they prefer to advise the use of pesticides is that the profit margins of synthetic pesticides are in the order of $25 \%$ or more, while they are only about $5 \%$ for biocontrol 
agents. Further, sales people and extension service personnel providing information about pest management often discourage the application of biocontrol by referring to it as being too complicated to use. Next, most people now involved in crop protection matters - from the highest level in ministries of agriculture down to farmers and their workers - have been raised under the mantra that 'the only good insect is a dead insect, and chemical control is able to kill insects fast and cheaply'. The result is that many crop protection advisors and farmers are pesticide addicted after having heard this mantra for 70 years, and this addiction appears to be hard to heal by the relatively small numbers of experts in the field of biocontrol.

Another factor often mentioned in the chapters in this book is also related to chemical pesticide use and concerns obstructing the ecosystem function of natural pest control as a result of pesticide applications. The effect of this is that other primary pests need to be sprayed as well, and that secondary pests, which are kept at low densities by naturally occurring beneficial organisms, start to create serious problems. The dramatic negative effect of pesticides in the reduction of biodiversity, including beneficial species like biocontrol agents, has been documented during the past decades and culminated in the 2019 assessment by the Intergovernmental Science-Policy Platform on Biodiversity and Ecosystem Services (IPBES, 2019). Many policy makers and pesticide-industry representatives repeat over and again that agriculture has to feed some 10 billion people by the year 2050 and that, for this reason, a substantial increase in food production is needed, which can only be achieved using synthetic pesticides. Van Lenteren et al. (2018) discussed, documented and explained why this reasoning is simplistic, erroneous and misleading. Related to the topic of this book - biocontrol - the above reasoning is simplistic, because by stating that synthetic pesticides are needed for increased food production, the presence of a multitude of other approaches to pest, disease and weed control illustrated in this book and in many other publications is ignored.

A third factor related to pesticides hampering the implementation of biocontrol and other non-chemical pest management methods is the unrealistically low cost of chemical products.
Application of the 'true cost' principle for pesticides would strongly increase the market for biocontrol. Pesticides are currently 'subsidized' by governments because the industry is not held responsible for human illnesses and deaths as a result of chronic exposure to pesticides. Also, the pesticide industry does not have to provide funding for repairing damage done to the environment, such as reduction of biodiversity and inhibition of the functioning of the ecosystem services of pest control, pollination and cleaning of water. The pesticide costs related to all these harmful effects are externalized and paid for by society, while the pesticide industry only picks up the economic benefits without being responsible for the true costs. Realistic pricing involving these true costs would result in chemical pesticides being two to four times more expensive (van Lenteren et al., 2018), with the positive effect of fairer competition with non-chemical alternative control methods such as biocontrol.

Looking ahead, pest management in Latin America and the Caribbean (as elsewhere) will have to become more sophisticated, adaptable, flexible and sustainable than simply applying synthetic pesticides. This capacity will need to be developed in a changing world, where consumers will want and expect healthier produce, while climate change has the potential to substantially disrupt pest management (and society). Climate-smart pest management (Heeb et al., 2019) incorporating all the potential of biocontrol will be required. Researchers will have to develop new effective IPM strategies, extension staff will need to understand the IPM strategies in order to promote them and farmers will want access to advice and information on IPM, including biocontrol, delivered by the most suitable methods using appropriate information communication technology. Inevitably, it will take time to make this transition. Universities and technical training facilities should have the wherewithal (resources, suitable staff, information and material) to produce the next generation of researchers and extension staff who understand the role of biocontrol and IPM. They will then be able to generate and apply appropriate strategies to optimize agricultural and forestry production and protect the environment and biodiversity. Demonstrating how well beneficial agents can control pests, diseases and weeds, as is done in this book (published both in Spanish and in 
English), will be a valuable resource for this and should help to promote a wider appreciation for and application of biocontrol as part of IPM.

Many countries in the region mention lack of funding for research in biocontrol as a main reason for the few projects realized and this particularly plays a role in Central America and the Caribbean. Sometimes limited funding is temporarily provided when a new invasive pest is observed, resulting in ad hoc trials to apply biocontrol, but if quick success is not obtained these projects are prematurely terminated and, often incorrectly, the conclusion is drawn that biocontrol does not work. Other countries mention that research funding is available, but that collaboration among universities, institutes, extension services and farmers needs to be improved (e.g. Argentina, Bolivia, Brazil and Venezuela).

Time-consuming and expensive registration procedures for natural enemies and microbial control agents are also often mentioned as a limiting or even prohibiting factor, because many of the relatively small biocontrol agent producers are not able to bear those high registration costs. Chapter 1 of this book mentions that procedures for registration vary widely in Latin America and the Caribbean, and this is also the case for regulations for import and release, and for demands for environmental risk assessments of biocontrol agents. Colmenarez et al. (in preparation) propose the formation of a regional platform for harmonization of procedures related to biocontrol.

A recent regulation concerning prospecting for exotic natural enemies resulted in an almost complete stop in searching for exotic control agents. Under the Convention on Biological Diversity (CBD, 1993), countries have sovereign rights over their genetic resources and agreements governing the access to these resources and the sharing of benefits arising from their use need to be established between involved parties, i.e. Access and Benefit Sharing (ABS) (Cock et al., 2010). The Nagoya Protocol, which came into force in October 2014, is a supplementary agreement to the CBD and provides a framework for the implementation of ABS procedures. The consequence of this protocol is that currently a permission to survey and sample potential biocontrol agents can only be granted by the country that has the rights over the genetic resources, and that collection of new natural enemies has become increasingly difficult or impossible in countries that have first accidentally exported the pest, a situation which seems quite unreasonable.

Linked to the issues raised by the Nagoya Protocol is the need for taxonomic expertise to support agriculture and pest management (Lyal et al., 2008). Apart from issues relating to the identity of pests and their infraspecific variation, there is the challenge of the taxonomy of the biocontrol agents, both those used for classical introductions and inundative releases, and the indigenous natural control agents found in farmers' fields. Names are needed to understand what is happening, recognize the different species and provide clarity regarding their roles and functions. Taxonomists able to support this work are few in number and often scattered across museums and universities, both within Latin America and the Caribbean and across the world. It is important that these taxonomists are supported, their numbers increased and key linkages with pest management built and sustained. Molecular tools to extract genetic information are a valuable tool for taxonomists today, enabling them to achieve far more in less time, but this depends on the ability to move specimens and genetic information freely between taxonomists and researchers and across national borders. Regulations put in place to implement the Nagoya Protocol are intended to ensure equitable sharing of the benefits arising from access to genetic resources, but already they are impeding important taxonomic and applied pest management research based on biological specimens (i.e. genetic resources). It is important that these regulations facilitate rather than impede these public-good activities, as was specified in the Nagoya Protocol itself.

Another reason for initial reservations in using biocontrol relates to the opinion that biocontrol often fails. This opinion seems to be supported by the various unsuccessful cases mentioned in many of this book's chapters. It is a fact that a lot of early attempts to introduce and establish natural enemies did not result in establishment of the natural enemy, and establishment often did not lead to control of the target pest. Early failures to obtain establishment might have been caused by a multitude of reasons, such as: (i) poor and long transport conditions 
resulting in high mortality and low quality of the imported and released natural enemies; (ii) bureaucratic and time-consuming import procedures at custom offices leading to death of the biocontrol agents; (iii) too low numbers of released individuals; (iv) inadequate synchronization between release of the natural enemy and presence of the pest; (v) lack of preceding research on agroecosystem characteristics where biocontrol agents should be functioning, including knowledge about already present natural enemies that might prevent establishment; and (vi) insufficient climate matching. Early failures to establish or have impact were also the result of the 'hit-and-miss' or 'shotgun' approach often followed until the 1990s: 'release every biocontrol agent that you can get hold of, and something should work'. However, the FAO Guidelines for the export, shipment, import and release of biocontrol agents and other beneficial organisms (IPPC, 2017), which were first issued in 1996 (IPPC, 1996) now help to guide many Latin American and Caribbean countries (Kairo et al., 2003). Risk assessment procedures, as well as new approaches for agent selection that are explained in Chapter 1 of this book, allow for early exclusion of ineffective or problematic candidate species.

The increased investment in evaluating the risks and potential of new biocontrol agents, particularly for insect biocontrol agents to control insects, has reduced the number of biocontrol agent species introduced, but increased the establishment and success rate (Cock et al., 2016). In contrast, from very early on, weed biocontrol involved the careful selection and detailed evaluation of potential biocontrol agents, leading to higher establishment and success rates than for insect biocontrol (Schwarzländer et al., 2018). Although establishment and success rates in biocontrol have increased over time, it is, surprisingly, not uncommon to read in papers written by biocontrol experts that this success rate is still low. Actually, the success rate is surprisingly high: a comparison of the success rate and costs involved in the identification of a marketable synthetic pesticide $(1: 140,000$ and US\$256 million) and the success rate and costs involved in finding an effective natural enemy for augmentative biocontrol (1:10 and US\$2 million) demonstrates the good success rate and low costs at which a success is obtained with biocontrol (data for 2010). Details and references illustrating this issue are given in van Lenteren (2012).

\section{Factors stimulating development and implementation of biological control}

Compared with chemical pesticides, biocontrol agents show a number of inherent characteristics that make them preferred pest management tools now and in the future.

- They are less detrimental to the health of farm workers and those living in farming communities.

- Use of biocontrol does not imply a "crop re-entry period' as is the case with most pesticides, and lack of this re-entry period makes continuous harvesting possible, which is particularly important with fresh products such as vegetables, fruit and ornamentals where market prices may vary strongly even during a day.

- They are more sustainable, as there has been no development of resistance against arthropod biocontrol agents.

- They do not cause phytotoxic damage to plants and, as a result, farmers report better yields and healthier crops after switching to biocontrol.

- Use of biocontrol results in residue-free or residue-poor products and, increasingly, produce will only be bought by exporters and local retailers when residue levels are well below the legal maximum residue levels (MRLs).

- Finally, reduction in or absence of chemical pesticide applications as a result of using biocontrol leads to increased biodiversity in and around crops.

Many of these inherent characteristics are not well known or explained to farmers and consumers, and several chapters in this book refer to this lack of knowledge. Documentation of the many successes obtained with biocontrol, as done in this book, as well as providing data showing that biocontrol can be cheaper than chemical control (see Chapter 6: Brazil and Chapter 25: Peru), may encourage farmers, consumers and policy makers to accept this sustainable pest management method. 
Interesting specific factors for the Latin American and Caribbean region that stimulate implementation of biocontrol are the many prospecting projects and the large number of documented cases of natural pest control. Prospecting gives an insight into the many potential biocontrol candidates (e.g. Chapter 19: Honduras, Chapter 20: Jamaica and Chapter 24: Paraguay) and regional prospecting has resulted in many natural enemies and microbial agents that are now mass produced and released for augmentative biocontrol. Documentation of natural control not only illustrates the positive role of the ecosystem service of pest control, but also helps in understanding why excessive pesticide sprays interfere with this free pest control service and may result in causation of secondary pests.

Many countries mention that new invasive pests initiate new biocontrol research. As mentioned earlier, an interesting approach to try to solve problems caused by new invaders is used in Mexico, by first determining pest risk scenarios and then reviewing possibilities for biocontrol before these pests cause problems. Recent pest invasions in the region, e.g. pink hibiscus mealybug and papaya mealybug, have shown that regional cooperation can result in area-wide solutions using biocontrol. Regional cooperation seems a very positive option to stimulate biocontrol.

At the governmental level, adoption and funding of IPM and biocontrol approaches have a strong positive influence on application of biocontrol, as is explained for example in Chapter 5: Bolivia, Chapter 10: Cuba and Chapter 25: Peru. When such approaches are combined with concurrent measures to reduce chemical pesticide use as employed in Peru, the positive effect on application of biocontrol is even larger. Another important promoter of increased use of biocontrol is the availability of fast-track and priority registration of low-risk pest control agents such as biocontrol agents and a special registration procedure for microbial agents.

The chapters clearly show that organic food production and production of food under some form of certification for the export market is strongly growing in the Caribbean and in Central and South America. These forms of production stimulate the use of biocontrol. Also, local concerns about food safety and environmental impact issues in relation to synthetic pesticide use are mentioned in many chapters, resulting in a preference for low- or no-residue produce and a demand for biocontrol.

More efficient biocontrol agent selection methods (Chapter 1) and regional development of improved and more stable formulations for microbial biocontrol agents, cheaper and better quality production of natural enemies, and better application methods for biocontrol agents (e.g. equipment to release biocontrol agents in crops by use of drones or unmanned airplanes) also contribute to growth in uptake of biocontrol.

In conclusion: it is clear that the dominance of the chemical industry will not diminish soon, but governments, researchers, farmers and consumers are becoming increasingly aware of the negative effects of excessive pesticide use on the biosphere and its inhabitants, and this, together with the many positive effects of biocontrol, will result in a growth of this pest management method.

\subsection{Future of Biological Control in Latin America and the Caribbean}

In the chapters of this book, many largely varying issues are mentioned about the future of biocontrol in the region.

- Many countries anticipate a growth in application of all forms of biocontrol, because of the result of prospecting projects, increase in documentation and use of natural control, realization of more conservation biocontrol programmes as a result of better understanding of the role of insects in agroecosystem functioning, a large expansion of augmentative biocontrol after demonstration of large successes obtained in, for example, Brazil, and the long-term successes realized with classical biocontrol. Export demands for pesticide-poor or pesticide-free products are expected to boost all types of biocontrol.

- A lot of countries mention the future need of biocontrol to manage the many new invasive pests.

- A number of countries expect to increase governmental or industrial mass production of native natural enemies and, particularly, microbial agents to be able to meet 
growing demands. Production of pathogens and antagonists for biocontrol of diseases is explicitly mentioned in several chapters (e.g. Brazil, Chile, Colombia and Uruguay). Also, future implementation of qualitycontrol methods for biocontrol agents is thought by many countries to lead to better products, resulting in increasing sales.

- Anticipated continuation of current and future governmental support and guidance in development of biocontrol is mentioned by many countries.

- Several countries recognize an urgent need for harmonization of regulations for import and release of exotic biocontrol agents, as well as registration procedures. Current procedures are very diverse, resulting in the need to provide different documents for each country, leading to high costs that are difficult to cover for most of the small biocontrol companies. Harmonization is not expected to occur soon, but would certainly stimulate future application of biocontrol. A related problem that needs urgent action is to find a solution for the impasse in foreign exploration due to the Access and Benefit Sharing (ABS) issue that developed after acceptance of the Nagoya protocol (see Chapter 1 and above). The IOBC Global Commission on ABS (IOBC, 2019a) made an appeal to develop ABS regulations that support the biocontrol sector by facilitating the exchange of biocontrol agents, including development of clear guidelines. The Commission prepared best-practice guidelines for exchange of biocontrol genetic resources to assist the biocontrol community to demonstrate due diligence in complying with ABS requirements (Mason et al., 2018), which will hopefully facilitate the resumption of foreign prospecting for biocontrol agents.

- The Caribbean region and Central American countries refer to the importance of future cooperation in development and application of biocontrol, especially for classical control of new area-wide invasive pests. Strengthening of the role of international institutions mentioned in Chapter 1 in coordination of biocontrol projects involving similar pests, diseases and weeds occurring in a number of countries in the region, and improved cooperation between countries, for example within the Neotropical Regional Section of IOBC (IOBC, 2019b), might help in realizing more biocontrol projects with the limited amount of national funding. A priority activity for regional cooperation in collaboration with FAO might be to compile a list of future invading organisms into the region and to identify potential biocontrol agents for management of these organisms.

- Several countries mention the need for training of technicians and farmers in the use of biocontrol. One option might be to do this via the farmer-participatory Farmers Field Schools system, which is currently implemented on several Caribbean islands with the aim of increasing the capability of farmers to use IPM and biocontrol and become less dependent on chemical control. See Chapter 27 (Remaining Caribbean Islands) for examples.

- Currently, few countries in Latin America and the Caribbean study or implement biocontrol of weeds and vectors of human and animal diseases, while much knowledge is available about biocontrol of these organisms elsewhere in the world. These are clearly areas for future attention in the region. The same holds, though for fewer countries, for biocontrol of plant diseases.

- Although a number of countries face serious economic problems that have repercussions on research, agriculture and forestry remain priority activities in these countries and in the region as a whole. Modernization of agriculture and forestry is proceeding rapidly in Latin America and the Caribbean, and the many examples of cutting-edge biocontrol projects provided in this book assist in this modernization process. Biocontrol further contributes to sustainable food production and protection of biodiversity of the region's many nowthreatened natural areas.

\subsection{Acknowledgements}

Vanda H.P. Bueno is thanked for compiling the multipage list provided as supplementary material with names of all organisms (biocontrol agents, 
pests, crops, weeds, etc.) with author name, order, family and common name of the organism, and the country chapters in which these organisms are mentioned. CABI is an international intergovernmental organisation, and
M.J.W. Cock gratefully acknowledges the core financial support from CABI's member countries (see https://www.cabi.org/what-we-do/ how-we-work/cabi-donors-and-partners/ for full details).

\section{References}

Cock, M.J.W. (ed.) (1985) A Review of Biological Control of Pests in the Commonwealth Caribbean and Bermuda up to 1982. Technical Communication No. 9, Commonwealth Institute of Biological Control. Commonwealth Agricultural Bureaux, Farnham Royal, UK.

Cock, M.J.W. (2019) Unravelling the status of partially identified insect biological control agents introduced to control insects: an analysis of BIOCAT2010. BioControl 64, 1-7. DOI: 10.1007/s10526-018-09921-1

Cock, M.J.W., van Lenteren, J.C., Brodeur, J., Barratt, B.I.P., Bigler, F. et al. (2010) Do new access and benefit sharing procedures under the convention on biological diversity threaten the future of biological control? BioControl 55, 199-218.

Cock, M.J.W., Murphy, S.T., Kairo, M.T.K., Thompson, E., Murphy, R.J. and Francis, A.W. (2016) Trends in the classical biological control of insect pests by insects: an update of the BIOCAT database. BioControl 61, 349-363. DOI: 10.1007/s10526-016-9726-3

CBD (Convention on Biological Diversity) (1993) Convention on Biological Diversity (with annexes). Concluded at Rio de Janeiro on 5 June 1992. United Nations - Treaty Series 1760(30619), pp. 142-382.

Hajek, A.E., Gardescu, S. and Delalibera Jr, I. (2016) Classical Biological Control of Insects and Mites: A Worldwide Catalogue of Pathogen and Nematode Introductions. FHTET-2016-06. Forest Health Technology Enterprise Team, Morgantown, West Virginia. Available at: https://www.fs.fed.us/foresthealth/technology/pub_titles.shtml (accessed 17 May 2019).

Heeb, L., Jenner, E. and Cock, M.J.W. (2019) Climate-smart pest management: building resilience of farms and landscapes to changing pest threats. Journal of Pest Science 92(3), 951-969. DOI: 10.1007/ s10340-019-01083-y

IOBC (2019a) IOBC Global Commission on ABS. Available at: http://www.iobc-global.org/global_comm bc_access_benefit_sharing.html (accessed 5 August 2019).

IOBC (2019b) International Organisation for Biological Control: Neotropical Regional Section. Available at: www.iobcntrs.org (accessed 5 August 2019)

IPBES (Intergovernmental Science-Policy Platform on Biodiversity and Ecosystem Services) (2019) Assessment Reports on Biodiversity and Ecosystem Services. Available at: https://www.ipbes.net/ assessment-reports (accessed at 31 May 2019).

IPPC (1996) Code of Conduct for the Import and Release of Exotic Biological Control Agents. International Standards for Phytosanitary Measures No. 3. Food and Agriculture Organization of the United Nations (FAO), Rome.

IPPC (2017) Guidelines for the export, shipment, import and release of biological control agents and other beneficial organisms. International Standards for Phytosanitary Measures No. 3. Food and Agriculture Organization of the United Nations (FAO), Rome. Available at: https://www.ippc.int/static/media/files/publication/ en/2017/05/ISPM_03_2005_En_2017-05-23_PostCPM12_InkAm.pdf (accessed at 17 May 2019).

Kairo, M.T.K., Cock, M.J.W. and Quinlan, M.M. (2003) An assessment of the use of the Code of Conduct for the Import and Release of Exotic Biological Control Agents (ISPM No. 3) since its endorsement as an international standard. Biocontrol News and Information 24, $15 \mathrm{~N}-27 \mathrm{~N}$.

Lyal, C., Kirk, P., Smith, D. and Smith, R. (2008) The value of taxonomy to biodiversity and agriculture. Biodiversity 9, 8-13.

Mason, P.G., Cock, M.J.W., Barratt, B.I.P, Klapwijk, J., van Lenteren, J.C., Brodeur, J., Hoelmer, K.A. and Heimpel, G.E. (2018) Best practices for the use and exchange of invertebrate biological control genetic resources relevant for food and agriculture. BioControl 63, 149-154. DOI: 10.1007/s10526017-9810-3.

Schwarzländer, M., Hinz, H.L., Winston, R.L. and Day, M.D. (2018) Biological control of weeds: an analysis of introductions, rates of establishment and estimates of success, worldwide. BioControl 63, 319-331. DOI: 10.1007/s10526-018-9890-8. 
van Lenteren, J.C. (2012) The state of commercial augmentative biological control: plenty of natural enemies, but a frustrating lack of uptake. BioControl 57, 71-84 + supplemental material. DOI: 10.1007/ s10526-011-9395-1

van Lenteren, J.C. and Bueno, V.H.P. (2003) Augmentative biological control of arthropods in Latin America. BioControl 48, 123-139.

van Lenteren, J.C., Bolckmans, K., Köhl, J., Ravensberg, W.J. and Urbaneja, A. (2018) Biological control using invertebrates and microorganisms: plenty of new opportunities. BioControl 63, 39-59 + supplemental material. DOI: 10.1007/s10526-017-9801-4

van Lenteren, J.C., Bueno, V.H.P and Klapwijk, J. (2019) Augmentation biological control. In: Mason, P.G. (ed.) Biological Control: A Global Endeavour. CSIRO Publishing, Clayton, Australia.

Zúñiga, E. (1985) Ochenta años de control biologico en Chile. Revision historica y evaluacion de los proyectos desarrolados (1903-1983) [Eighty years of biological control in Chile. Historical review and evaluation of project undertaken (1903-1983)]. Agricultura Técnica 45(3), 175-183. 